\title{
A CLINICAL STUDY OF THE ACTION OF 10 COMMONLY USED DRUGS ON CARDIAC OUTPUT, WORK AND SIZE; ON RESPI- RATION, ON METABOLIC RATE AND ON THE ELECTROCARDIOGRAM
}

\author{
By ISAAC STARR, C. J. GAMBLE, A. MARGOLIES, J. S., DONAL, JR., N. JOSEPH \\ AND E. EAGLE \\ (From the Departments of Research Therapeutics, and of Pharmacology, the Robinette Foun- \\ dation, and the Medical Division of the Hospital of the University of \\ Pennsylvania, Philadelphia)
}

(Received for publication March 22, 1937)

The possession of a technique which permitted rapid estimations of cardiac output and which, demanding no intelligent cooperation, seemed especially suitable for use on ward patients, has permitted an extensive study on the action of common drugs on the heart and circulation in clinical conditions. This study contains about 450 estimations of cardiac output performed on 85 patients.

Coincidentally with these estimations the action of drugs on pulse rate, on blood pressure, on respiratory rate and volume, and on metabolic rate was observed. Orthodiagrams and electrocardiograms were secured also. Therefore, certain parts of our study dealt with effects already well known.

The results of such estimations have permitted the calculation of heart work, of peripheral resistance, of arteriovenous oxygen difference, and of the ratio of heart work to heart size, the latter a factor of decisive importance in our conception of cardiac stimulation and depression. Therefore our study demonstrates the effect of drugs on these functions also.

Most of the drugs selected are commonly used in cases of cardiac and circulatory disease. We have studied the actions of digitalis, epinephrine, ephedrine, caffeine, theophylline, carbaminoylcholine, sodium nitrite, nitroglycerine, pitressin, quinidine, morphine and strychnine. We have studied the effects of drugs in those clinical conditions in which physicians are accustomed to employ them. But when suitable cases were not available the effects were studied in other conditions.

Almost without exception our results support the general conceptions of drug action derived from animal experiments.

\section{PROCEDURE}

All estimations were performed in the morning. The patients received no food after their evening meal and no water after midnight. They were taken from the ward in bed or in a wheel chair. An electrocardiogram and an orthodiagram were obtained first. Then the subjects lay down for at least $\mathbf{4 5}$ minutes. Duplicate estimations of cardiac output and metabolism were then made, together with repeated determinations of pulse rate, blood pressure, respiratory rate and volume.

If the study concerned a rapidly acting drug, this was administered soon after the control estimations. The patient was watched until evidence of the drug's action became manifest objectively. Duplicate estimations of cardiac output and metabolism were then made, the purpose being to make these determinations at the height of action. Orthodiagrams and electrocardiograms were secured immediately afterward.

Cardiac output was estimated by the method of Starr and Gamble (1), the analyses being performed by the katharometer method of Donal, Gamble and Shaw (2). Metabolism was estimated from samples of expired air drawn from a mixing bottle containing a fan.

Respiratory volume was obtained by reading the spirometer at frequent intervals. Respiratory rate was counted repeatedly during the period of observations. It is well known that subjects breathing from a spirometer under $3 \mathrm{~mm}$. $\mathrm{H}_{2} \mathrm{O}$ negative pressure, and through valves, tend to breathe somewhat deeper and more slowly than under normal conditions.

The left ventricular work was calculated as described before (3). The peripheral resistance was calculated from the formula used by Bazett et al. (4).

The volume of the heart was estimated from Kahlstorf's formula (5).

The analyses concerned with estimating cardiac output were performed by Donal, those concerned with metabolism by Joseph, Donal or Eagle. The orthodiagrams were made by Margolies. Starr selected the patients from the wards and decided on the drug and dosage suitable for them. Gamble or Starr administered the drugs and, with Joseph, made clinical observations. The statistical analysis was carried out by Starr and Joseph with the assistance of Dr. H. A. Schroeder. 
We are indebted to Dr. L. H. Collins for clinical help in the spring of 1934, to many of the staff and interns of the University Hospital for assistance in securing patients and in adopting the therapy employed to assist this study, and especially to our many patients who so willingly cooperated.

\section{Conclusions from results obtained by cardiac output methods}

Before the results can be discussed with profit certain conceptions fundamental to our viewpoint must be set forth. The first concerns our method of drawing conclusions from our results. A second group has to do with basic conceptions of cardiac physiology in relation to which our results will be presented. Our approach to this problem differs from that of certain other workers in this field and this difference must be discussed in detail.

Grollman (6) describes his method as accurate to 10 per cent, i.e. changes of less than this amount might be accounted for by errors inherent in technique and analysis. This conception is supported chiefly by a long series of estimations made on a normal subject who gave results varying within this limit. That changes of less than 10 per cent are not significant is thus rendered probable, but one should not conclude that all changes greater than 10 per cent are significant. To give a patient a drug and to attribute to its action any change of cardiac output of over 10 per cent would be highly hazardous. Duplicate estimations of cardiac output by the acetylene method differ by far more than 10 per cent in many patients. Our method shows similar variations. Standards derived from the best subjects under ideal conditions cannot be used with safety to estimate the significance of differences in clinical work. It is not sufficient to estimate variability due to errors inherent in the method. There is a large variability inherent in subjects, who may change their cardiac outputs due to apprehension and excitement, or induce irregular errors due to poor cooperation. Unless this type of error is considered the conclusions drawn may be highly erroneous.

We have, therefore, employed statistical procedures to estimate the significance of our differences. The method is not a perfect one for our purpose, but it provides the best criterion for the significance of quantitative data. A detailed discussion of the means employed follows.

In order to estimate the significance of average results obtained on a number of patients given a single drug we have followed exactly the procedure given by Fisher (7, page 104) and made use of his Table IV, to obtain the probabilities. We have defined significance in the customary manner, i.e. a probability larger than 95 in 100 that the result obtained was not due to chance. But we wish to point out that this definition is arbitrary and probably too rigid for clinical work in which physicians constantly are being forced to make important decisions based on data whose probability of error is enormously greater than 5 in 100 . Therefore when, after the administration of certain drugs, we have not demonstrated changes of sufficient magnitude and constancy to merit the term significant, we do not imply that these smaller changes should be neglected. They often represent a better picture of the drug's action in clinical conditions than was available before, although not as perfect as one would like. When data become more ample the significance of the smaller changes may be established.

Since no two patients are identical, the question might be raised whether it was proper to draw conclusions from an average of the results obtained. The answer is that we are doing the best we can with the data at our disposal. In the future when series of more similar conditions and dosages are available, more accurate conclusions can be drawn concerning the action of drugs under special circumstances.

Something must be said concerning our ideas of the conclusions which should be drawn from the results obtained from one or two estimations of cardiac output, made on one patient before and after the administration of a drug or other agent. The discussion which follows probably applies to results obtained by Grollman's acetylene method also, for the variation of duplicate estimations found by Nylin (8) on patients by this method agrees closely with that we obtain on patients by our method.

Single estimations, before and after the administration of a drug, give one no knowledge of the spontaneous variability inherent in method and subject, and this makes accurate conclusions im- 
possible unless other data on variability are available.

Duplicate estimations, before and after, provide one with a very imperfect measure of the inherent variability, and the data can be handled statistically. They may be considered as two experiments and handled, as we have handled the larger series, according to Fisher (7, Section 24). A very steady subject will have to be used or a very large change found before significance can be attained.

However, long experience with a method permits one to set up other criteria. We have proceeded as follows. A sample was taken consisting of the last 65 pairs of duplicate estimations made on patients in this investigation. The standard deviation computed from the deviation of each of the duplicates about the mean of each pair was found to be 5.6 per cent.

An example will make our procedure clear. Below we calculate a testing standard deviation from two pairs of duplicates in the same manner as was employed for the 65 pairs.

\begin{tabular}{|c|c|c|c|c|}
\hline Patients & $\begin{array}{c}\text { Duplicate } \\
\text { cardiac } \\
\text { outputs }\end{array}$ & $\begin{array}{l}\text { Mean of } \\
\text { duplicates }\end{array}$ & $\begin{array}{c}\text { Deviation } \\
\text { from mean }\end{array}$ & $\begin{array}{l}\text { Deviation from } \\
\text { mean of devia- } \\
\text { tions squared }\end{array}$ \\
\hline A & $\begin{array}{c}\text { liters per } \\
\text { minute } \\
3.0,3.2\end{array}$ & 3.1 & $\begin{array}{l}\text { per cent } \\
+3.2 \\
-3.2\end{array}$ & $\begin{array}{l}10.2 \\
10.2\end{array}$ \\
\hline \multirow[t]{2}{*}{ B } & $4.0,4.6$ & 4.3 & $\begin{array}{r}+7.0 \\
-7.0\end{array}$ & $\begin{array}{l}49.0 \\
49.0\end{array}$ \\
\hline & & \multicolumn{2}{|c|}{$\begin{array}{l}\text { mean of deviations }=0 \\
\sigma=\sqrt{\frac{118.4}{4}}=5.4 \text { per cent }\end{array}$} & $\Sigma 118.4$ \\
\hline
\end{tabular}

If one has duplicate estimations before and after the condition inducing change: standard deviation of difference between the means $=\sqrt{\frac{\sigma^{2}}{2}+\frac{\sigma^{2}}{2}}$.

If one has only one observation before and after: standard deviation of difference between individual estimates $=\sqrt{\frac{\sigma^{2}}{1}+\frac{\sigma^{2}}{1}}$.

Estimates of the probabilities for any difference may be obtained from Fisher's Table ( 7, p. 139). In actual practice it is more convenient to think in terms of differences between the results of two estimates, expressed in percentage of their mean, than in the deviations from their means. The first is, of course, twice the second. In the text the conclusions have been expressed in terms of differences.

At the suggestion of Dr. J. H. Austin this standard deviation, 5.6 per cent, was checked by an estimation from the median divided by 0.955 , a figure derived from Pearson (9), which gave an identical value. We propose to use this figure, 5.6 per cent, as a testing standard deviation, a measure of the variability to be expected in the method applied to an average subject.

Employing this figure we find that when we have made one estimation before and one after the agent inducing change, differences between the results of $32,30,25,20$ and 10 per cent of their mean have probabilities of $95,94,88,60$ and 45 to 100 that they are not due to chance. Differences of over 32 per cent are significant.

If one has results of duplicate estimations before and after the agent studied, differences between the means of each pair of $22.4,20,15,10$ and 5 per cent have probabilities of $95,92,82,63$ and 45 to 100 that they are not due to chance. In this case differences of over 23 per cent are significant.

Obviously, when estimations are made on the same patient under the same conditions but on different days, the inherent variation is likely to be larger than in duplicate estimations on the same day. In order to make a basis for interpretation of prolonged experiments with drugs we have estimated the variability of the average of duplicate determinations obtained on one day with the same value found on a subsequent day. Discarding the trained subjects and also those patients whose clinical conditions had changed materially between the observations, the needed data were available on 18 patients, and the standard deviation was 7.7 per cent. Therefore, if the difference between the means of duplicate estimations was 30,20 or 10 per cent the probabilities would be 92,75 , and 44 in 100 that the difference was not due to chance. Differences of over 35 per cent are significant.

This use of a testing standard deviation has disadvantages which should be obvious; for example, some subjects, as cases of hyperthyroidism, are notoriously unstable, undergoing far larger fluctuations in cardiac output than the average subject. To use our testing standard deviation in such a case would be hazardous. Excessive divergence of duplicate estimates would aid in identifying some such cases but there is no way to protect oneself against the occasional error. We are chiefly concerned with recording the exact method by which we draw conclusions 
from our data. Then, if improvement in this method occurs to us or to others, correction of our conclusions will be easy. For this reason we have not increased our testing standard deviation by adding multiples of its standard error as is the practice of some statisticians in somewhat similar situations.

\section{Cardiac stimulation and depression}

In recent years drugs have been classified as cardiac stimulants or depressants when they increased or diminished contractility of cardiac muscle, as measured by levers attached in animal experiments. Soon after techniques for measurement of cardiac output were available, it became evident that the administration of these drugs was not always followed by a change in cardiac output in the direction which their action on preparations of cardiac muscle had led one to expect. In our opinion, results obtained by the two types of experiments can be reconciled if certain well known facts of circulatory physiology are kept in mind.

Most drugs which affect the heart act elsewhere on the circulation also and changes in the latter may cause secondary changes in cardiac behavior. Before a drug can be spoken of as stimulant or depressant to cardiac function the nature of the secondary changes must be carefully considered.

It seems obvious that the cardiac output is not dependent on the heart alone and that it should not be used as a test of cardiac capacity (10). The normal behavior of the heart, when its inflow and the resistance against which it works are changed, has been described by Starling (11) as follows : the work per beat of the normal heart is related to its size. This "Law of the Heart" also holds for clinical conditions, as closely as the relation between basal metabolic rate and body surface, and more closely than any similar relationship studied (12). From it has been derived a satisfactory definition of cardiac stimulation and depression. A heart is stimulated when its work per beat, in proportion to its diastolic size, increases. It is depressed when the reverse occurs (13). When one applies this definition to the drugs that we have studied the supposed dis- crepancies between the results obtained on man and in animal experiments largely disappear.

Therefore, we have estimated cardiac stimulation and depression by plotting our results in diagrams (Figures 1 and 2) showing the normal relationship between left ventricular work per beat and heart volume, derived from formula 2 , Table $\mathrm{V}$, of a previous paper (12). If the values are changed by the administration of drugs so that the point representing them moves upward or to the left we conclude that stimulation has occurred, for the heart's work in proportion to its size has increased. Movement to the right or down indicates cardiac depression. Movement parallel to the line $A B$ defines neither stimulation nor depression but represents the response a normal heart would make to changes elsewhere in the circulation, such as diminished venous return, increased arterial pressure, etc.

Difficulties in the clinical study of cardiac work are obvious. Only the work of the left ventricle can be estimated. There is some evidence from animal experiments that the work of the right ventricle is proportional to that of the left, but this could not be expected to hold in certain clinical conditions. Fortunately, the right ventricle's work is only a fraction of that of the left so that large percentage changes in right ventricular work would make but a small percentage change in the total cardiac work. There being no known method of estimating in the clinic the blood pressure in the pulmonary artery we have ignored the work contributed by the right ventricle in our calculations, although we are fully conscious of the errors which may be involved in certain instances such as mitral stenosis.

Bay (15) has suggested an ingenious method for estimating the amount regurgitated in aortic insufficiency. This gives accurate results on his schema, but it is not intended for use in the clinic. However, he has recalculated the left ventricle's work in three of our published cases and concludes that our estimate is far too small. Bay points out that, before his formula would yield an accurate result, the following conditions would have to obtain: (1) the usual blood flow to the tissues must be maintained, (2) the peripheral resistance must be unaltered, (3) elasticity must be normal. But there is evidence that peripheral resistance is reduced in aortic regurgitation (16), 

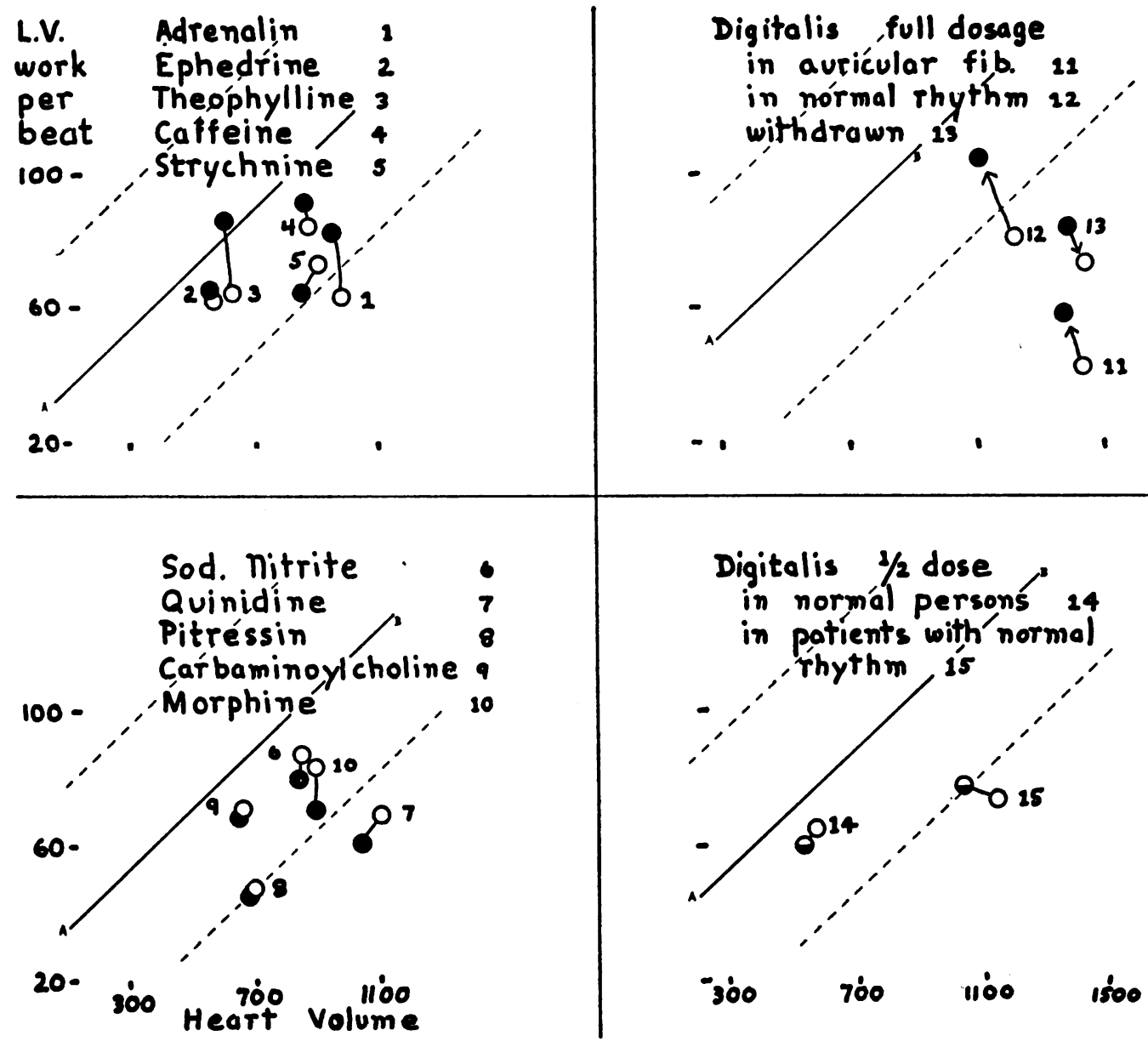

Fig. 1. Evidence of Cardiac Stimulation or Depression by Drug Action-Average Results

The solid lines $A B$ are the calculated best line for persons without heart disease. The outlying dotted lines have been placed at twice the standard deviation from $A B$ and define the normal zone, as in Figure 3 (12). According to our definition movement of points at right angles to $A B$, upwards and to the left, indicates cardiac stimulation, the reverse movement depression. The circles indicate the position of average values before drug administration, the solid dots are average values on the same patients during drug action.

Ordinates in grammeters per beat. Abscissae in $\mathrm{cm}^{3}$. The graphs are not absolutely identical with Figures 3, 4 and 5 (12) because a different method of calculating heart volume was used.

that distensibility decreases with age and in disease (17), and that normal blood flow is not always maintained (12). We also question the assumption that blood flow varies as the square root of the pressure applied, a condition well known to occur in hydraulics, and which doubtless holds for Bay's schema, but apparently not for the circulation (18). The expected deviation of most of these items from the basic assumptions of the formula would make the actual aortic leak far smaller than that calculated by Bay. The difficulties involved can be illustrated by pointing out that the formula as it stands will calculate the amount of "aortic leak" when applied to data from any case with a large pulse pressure, quite irrespective of evidence of the presence of aortic regurgitation. For these reasons we have not changed our method of calculating work in the cases of aortic regurgitation in this series. We gladly admit, as Bay points out, that each result is too small by the amount of the leak and welcome Bay's study as the first attempt to improve the estimation. Complete data have always been given in our tables to permit any one interested 


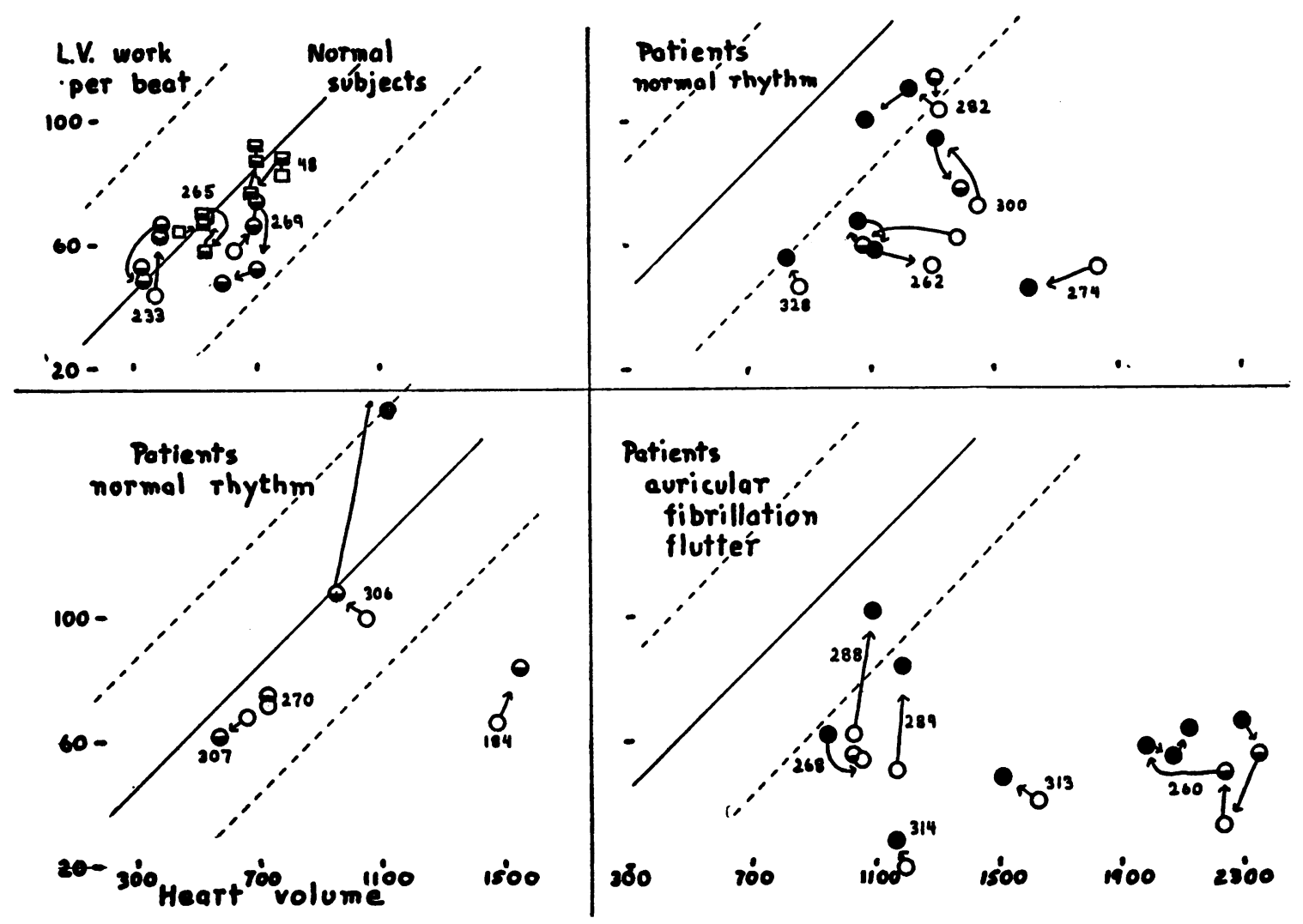

Fig. 2. Evidence of Cardiac Stimulation by Digitalis. Results in Individual Cases

Coordinates and lines as in Figure 1. Empty symbols indicate values in cases who had received no digitalis for 2 weeks or longer. Dots indicate values obtained during full digitalis action. Symbols half filled indicate the intermediate state, e.g. values obtained after half doses of digitalis, or in patients, previously exhibiting full action, who received no digitalis for one week. Case numbers correspond to data in Table III.

to recalculate the work according to newer and better methods as they become available. Being concerned with changes, the absolute values are of minor importance in this study.

\section{RESULTS}

The diagnoses, dosages, and other clinical data, together with the results on each case, have been assembled in Tables II and III at the end of the paper. The figures given for metabolic rate are averages of duplicate estimations, those for pulse rate, respiration, and blood pressure are averages of more numerous results.

The results of the statistical analyses have been summarized in Table $I$ also at the end of the paper. The probabilities are given as the next higher figure in Fisher's table, e.g.; 0.209 is recorded as 0.3 etc.
In Figure 3 the results have been presented in a graphic form which has been found useful for teaching medical students.

\section{Digitalis}

Every patient given this drug had severe cardiac disease; some had recently recovered from congestive failure, others were considered threatened with it, but none had constant râles at the lung bases or the other classic signs of this condition when our tests were made.

As several days must elapse before the effects of digitalis can be secured in the clinic, and about two weeks pass before such effects disappear after discontinuing the drug, the investigator is faced with the problem whether changes detected are due to action of the drug, or to changes in the patient's condition, either spontaneous or induced 


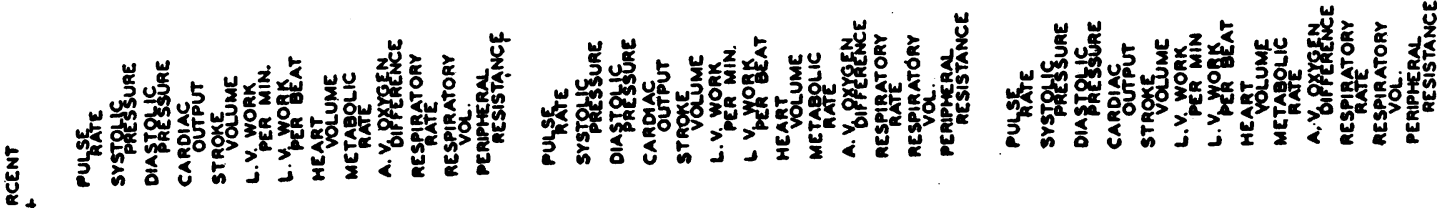

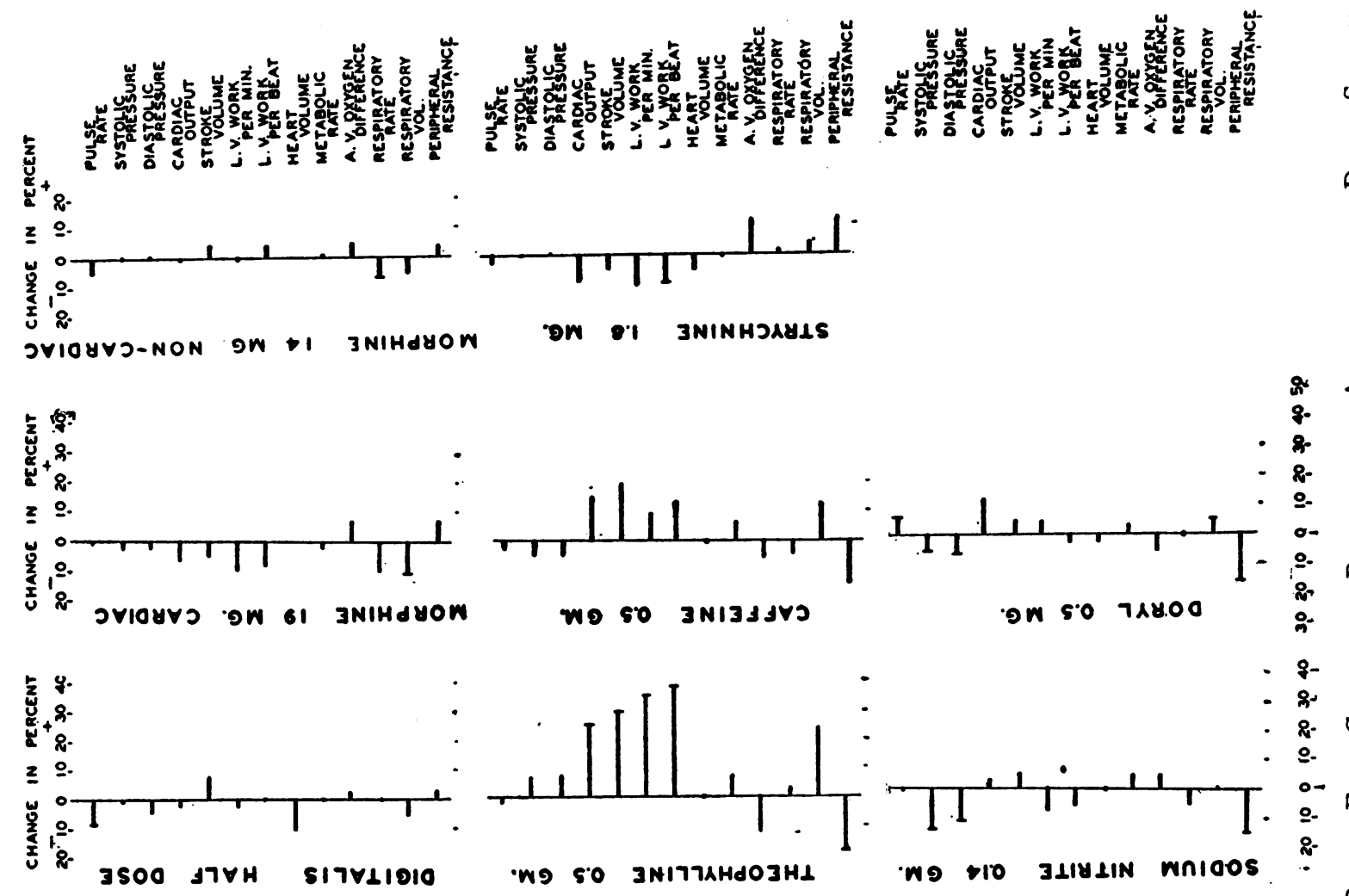

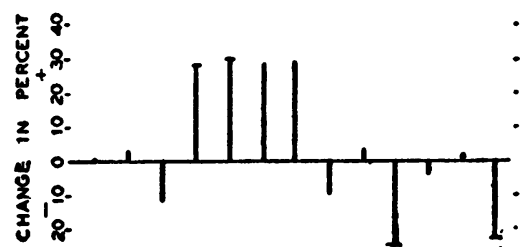

WHLAHY TVWYON SITVLIOIO

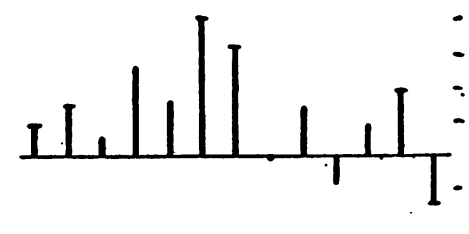

-ON CS 3NIYOJHdJ

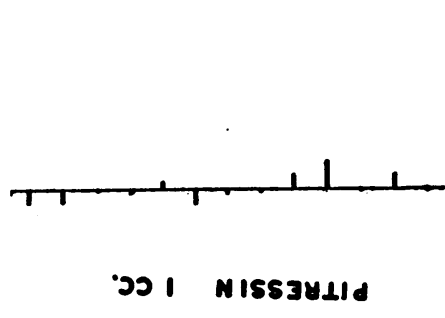

- क.

-

- 2 \&

은 웛

. 요 요

点

背
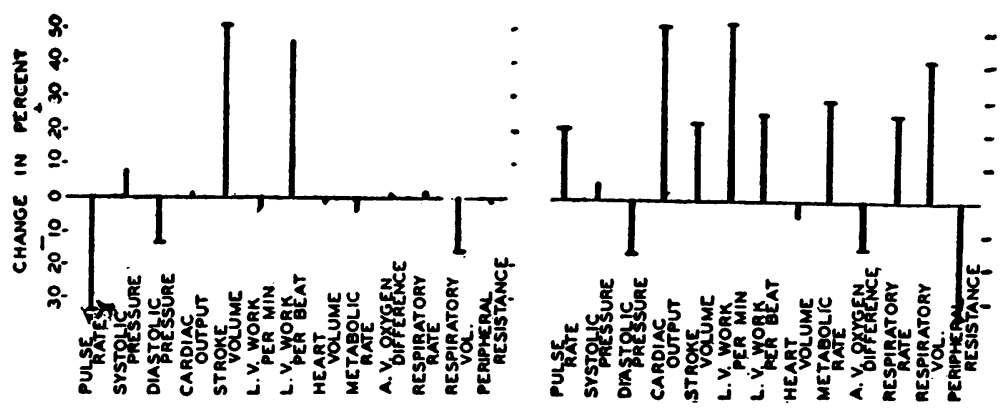

'ว 1000 NITỴNYOV

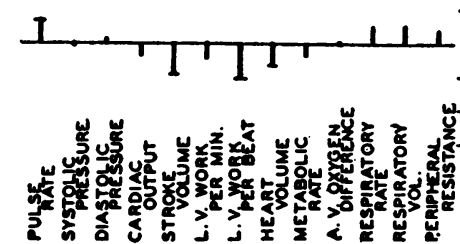

ㅇ. 눈

- 8-

- 8- 怒

- ㅇ. 돌

0- मि

- ㅇ- 는

的畺 ‥ 造 ठั लं 迎 
by rest, diet, and routine hospital care, factors quite sufficient to bring about improvement in most cardiac cases admitted to the wards. Therefore, we have attempted to safeguard our conclusions by two methods: (1) We have studied not only the effect of giving digitalis but also the effect of withdrawing it, when this maneuver did not conflict with the patient's well being. (2) We have questioned any change of cardiac output as evidence of digitalis action when it could be explained by a corresponding change of basal metabolic rate.

All the results are set forth in Table II. The well known digitalis effects on the electrocardiogram were seen in our cases and are indicated in Table II for comparison with the other data.

The results must be divided into three main groups, viz: those obtained on normal persons, in patients with auricular fibrillation, and in patients with cardiac disease with normal rhythm.

\section{Digitalis action in normal persons}

The four young or middle aged adults were given one-half the "therapeutic dose" of U. S. P. Tr. digitalis $(0.075 \mathrm{cc}$. per pound of body weight). They came to the laboratory without breakfast and rested in bed over an hour before the first group of estimations were made. Next day they took the drug by mouth at 8:00 a.m. and the procedure of the first day was repeated. Then they ate a light carbohydrate meal and a similar group of tests was made about 10 hours after the administration of the drugs. They returned to the laboratory fasting next morning, and on later mornings for the same studies. No subject had any very definite symptoms although one experienced malaise which might have been attributed to the drug.

The results show a consistent and significant increase in cardiac output 6 hours after the administration of the drug. Later the results were more irregular, and the averages did not show a significant change at any one time. In each subject, however, the increase was followed by a period in which both heart size and cardiac output were a little smaller than before the drug.

The reduced cardiac output following the administration of digitalis to normal subjects has been found by all who studied the subject and has had much emphasis $(19,20)$. The temporary increase we find has been reported before (21), but, not being found consistently, it has had little emphasis.

\section{Action of digitalis in heart disease with auricular fibrillation, or flutter}

We have had opportunity to study five such cases. The results are given in Table II.

In judging the effects of digitalis we have depended more on the well known clinical evidence than on the dosage given the patient.

Two of the cases were "fully digitalized" when first tested. Digitalis was withdrawn for two weeks and then given until effect on pulse rate was manifest. Two cases received it for the first time in our experiments.

In two instances the experiments were not entirely as we wished. Case 313 had received 0.18 gram of digitalis daily for 5 days before the first test; but he showed no evidence of action at that time and so has been regarded as not under the influence of the drug. Two weeks later, after receiving a much larger amount he became " fully digitalized." Case 268 with hyperthyroidism, after receiving no digitalis for 2 weeks, showed a marked drop in pulse rate after about half the dose usually required for such an effect. The simultaneous diminution in basal metabolic rate may explain the difference in cardiac rate and output, and conclusions concerning digitalis action cannot be drawn with safety. We have compiled statistics both including and excluding these two cases.

Averages compiled from observations made when the demonstrated effect on cardiac output was maximal, Figure 3 and Tables I and II, show that the significant effects of the drug in auricular fibrillation are the diminution of pulse rate, diastolic pressure, and volume of respiration, and the increase of stroke volume. The increase in work per beat escaped significance by the narrowest of margins. The cardiac output per minute was usually but little changed. One patient (Case 260), the sickest of the group, had such a large percentile increase that it balanced the effect of the remainder. Due to a rise of average systolic pressure the average pulse pressure was increased, the mean pressure changed but little. 
The exclusion of the two doubtful cases mentioned before does not change the conclusions materially. The average changes in pulse rate and work per beat are still significant. Those of work per beat, stroke volume and respiratory volume are as large as in the whole group but just miss significance because of the reduced number of cases.

Unlike the cases with normal rhythm, the average heart volume did not diminish in patients with auricular fibrillation. This apparent discrepancy may well be due to the marked slowing of heart rate in the latter group which, by allowing more time for filling during diastole, would increase the observed diastolic volume and mask the effect of the drug.

The effects of withdrawing digitalis were studied in Cases 260 and 268. The preceding effects of digitalis on pulse rate and respiratory volume were reversed in both cases. The cardiac output fell significantly in Case 260, it was changed but little in Case 268. Changes in heart volume were not noteworthy in either case.

The one case (Case 289) of auricular flutter available showed a significant increase of cardiac output after digitalis, a slight slowing of the pulse rate (Table II), and the results gave evidence of cardiac stimulation after the drug (Figure 2).

\section{Digitalis in heart disease with normal rhythm}

Eight cases fall into this group. In 6 we attempted to ascertain the effect of full doses of digitalis. In the absence of effect on pulse rate we counted chiefly on the electrocardiogram to tell us when the drug was acting. Difficulties were encountered in two cases. Case 274, probably with hyperthyroidism, had an elevated metabolic rate during the preliminary estimations; it was progressively much lower at the later tests so this result has been omitted from the statistics. Case 306, a young colored man accustomed to hard physical labor in spite of advanced rheumatic heart disease, had developed auricular fibrillation together with severe symptoms which brought him to the hospital. The arrhythmia ceased spontaneously and was replaced by persistent bradycardia. Recovery took place with unusual rapidity, beginning before full digitalis action was expected and continuing during six days when the drug was withdrawn. We suspected, therefore, that other factors than digitalis were at work. But finding no fault with the experiment except the unusual extent and rapidity of improvement under the drug, we have included it in the statistics.

The averages of results in the five best cases (Figure 3) show that the effect of full doses was to cause significant increase of cardiac output and stroke volume, and a significant decrease of $\mathrm{A}-\mathrm{V}$ oxygen difference and peripheral resistance. The heart volume was diminished markedly in 3 cases and unchanged in 2 . The average pulse rate was unchanged.

Attempts were made to test the effects of withdrawing digitalis in 5 cases. In Case 262, tested 12 days after withdrawal of the drug, the previous effects of its action were reversed. In Case 282,13 days after withdrawal, the cardiac output was slightly smaller but there was little change in the other functions. Seven days after withdrawal, Case 300 showed a slight decrease in cardiac output also. However, in Case 274 the cardiac output increased in spite of withdrawal of the drug for 12 days; doubtless this may be attributed to the general clinical improvement taking place simultaneously.

In 4 cases, all with normal rhythm, tests were made to determine whether small doses had any effect. Cases 262, 306 and 307 were given 0.0075 gram per pound, half the dose calculated to produce full effects; Case 270 was given a still smaller dose. The average reduction in pulse rate was small but significant. Changes in cardiac output were always small, it diminished in 3 cases and was unchanged in one. In Case 270 this fall is coincident with a fall in basal metabolic rate and may not be due to the drug. The heart volume diminished in 3 of the 4 cases but the average change is not significant (Figure 3, Tables I and II).

These "small" doses of digitalis appeared to exert slight effects on pulse rate, heart size, and on the electrocardiogram of these patients. The normal subjects taking a similar dose showed the two latter effects but there was no noteworthy effect on their pulse rates.

The average pulse rate was more slowed by " half" doses than by "full" doses of digitalis. 
TABLE I

Statistics on the effect of drugs on heart, circulation, respiration and metabolic rate*

\begin{tabular}{|c|c|c|c|c|c|c|c|c|c|c|c|c|c|c|c|}
\hline \multirow{2}{*}{ Drug and remarks } & \multirow{2}{*}{$\begin{array}{l}\text { Num- } \\
\text { ber of } \\
\text { cases }\end{array}$} & \multirow{2}{*}{$\begin{array}{c}\text { Aver- } \\
\text { sge } \\
\text { dose }\end{array}$} & \multirow{2}{*}{$\begin{array}{l}\text { Pulse } \\
\text { rate }\end{array}$} & \multicolumn{2}{|c|}{ Blood pressure } & \multirow{2}{*}{$\begin{array}{c}\text { Cardiac } \\
\text { output }\end{array}$} & \multirow{2}{*}{$\begin{array}{l}\text { Stroke } \\
\text { volume }\end{array}$} & \multirow{2}{*}{$\begin{array}{c}\text { Left } \\
\text { ventrio- } \\
\text { ular } \\
\text { work per } \\
\text { minute }\end{array}$} & \multirow{2}{*}{$\begin{array}{c}\text { Loft } \\
\text { ventrio- } \\
\text { ular } \\
\text { work per } \\
\text { beat }\end{array}$} & \multirow{2}{*}{$\begin{array}{c}\text { Heart } \\
\text { volume }\end{array}$} & \multirow{2}{*}{$\begin{array}{l}\text { Meta- } \\
\text { bolic } \\
\text { rate }\end{array}$} & \multirow{2}{*}{$\begin{array}{c}\text { Arterio- } \\
\text { venous } \\
\mathrm{O}_{2} \\
\text { difference }\end{array}$} & \multicolumn{2}{|c|}{ Respiration } & \multirow{2}{*}{$\begin{array}{l}\text { Periph- } \\
\text { eral } \\
\text { resist- } \\
\text { ance }\end{array}$} \\
\hline & & & & Systolic & \begin{tabular}{|l|} 
Diags \\
tolic
\end{tabular} & & & & & & & & Rate & Volume & \\
\hline $\begin{array}{l}\text { Digitalis (in auricular } \\
\text { fibrillation)......... }\end{array}$ & 5 & Full & \begin{tabular}{|c|}
-33.0 \\
0.01
\end{tabular} & $+\begin{array}{r}7.6 \\
0.8\end{array}$ & $\begin{array}{r}-12.2 \\
0.05\end{array}$ & $+\begin{array}{l}1.3 \\
1.0\end{array}$ & $\begin{array}{r}+50.5 \\
0.06\end{array}$ & $\begin{array}{r}-4.1 \\
0.8\end{array}$ & $\begin{array}{r}+45.0 \\
0.1\end{array}$ & $\begin{array}{r}-1.7 \\
0.5\end{array}$ & $-\begin{array}{r}3.5 \\
0.7\end{array}$ & $\begin{array}{r}0.7 \\
1.0\end{array}$ & $+\begin{array}{r}1.8 \\
0.8\end{array}$ & $\begin{array}{r}-15.9 \\
0.01\end{array}$ & $\begin{array}{r}-1.3 \\
1.0\end{array}$ \\
\hline Same, 3 best cases.. & 3 & Full & -37.1 & $\begin{array}{r}+15.2 \\
0.2\end{array}$ & $\begin{array}{r}-16.5 \\
0.8\end{array}$ & $\begin{array}{r}+10.3 \\
0.8\end{array}$ & $\begin{array}{r}+69.2 \\
0.1\end{array}$ & $\begin{array}{r}6.9 \\
0.8\end{array}$ & $\begin{array}{c}+68.6 \\
0.05\end{array}$ & $\begin{array}{r}-0.4 \\
1.0\end{array}$ & $+\begin{array}{r}4.9 \\
0.7\end{array}$ & $\begin{array}{r}4.0 \\
0.0\end{array}$ & $\begin{array}{r}2.9 \\
0.8\end{array}$ & $\begin{array}{r}-14.1 \\
0.8\end{array}$ & $\begin{array}{r}-3.3 \\
0.9\end{array}$ \\
\hline Digitalis (in normal rhythm).. & 5 & Full & $+\begin{array}{r}0.2 \\
1.0\end{array}$ & $+\begin{array}{r}2.8 \\
0.8\end{array}$ & $\begin{array}{r}-10.1 \\
0.4\end{array}$ & $\begin{array}{r}+28.2 \\
0.01\end{array}$ & $\begin{array}{r}+30.0 \\
0.05\end{array}$ & $\begin{array}{r}+27.9 \\
0.8\end{array}$ & $\begin{array}{r}+28.1 \\
0.1\end{array}$ & $\begin{array}{r}-8.0 \\
0.2\end{array}$ & $+\begin{array}{r}0.3 \\
1.0\end{array}$ & $\begin{array}{r}-20.5 \\
0.01\end{array}$ & $-\begin{array}{r}3.3 \\
0.4\end{array}$ & $+\begin{array}{r}2.1 \\
0.9\end{array}$ & $\begin{array}{r}-22.9 \\
0.01\end{array}$ \\
\hline Digitalis (in normal rhythm).. & 4 & $\begin{array}{l}\text { One- } \\
\text { half }\end{array}$ & $-\begin{array}{c}7.9 \\
0.02\end{array}$ & $-\begin{array}{r}1.0 \\
0.9\end{array}$ & $-\begin{array}{r}4.3 \\
0.4\end{array}$ & $\begin{array}{r}2.2 \\
0.7\end{array}$ & $+\begin{array}{r}7.0 \\
0.5\end{array}$ & $-\begin{array}{r}4.1 \\
0.6\end{array}$ & $+\begin{array}{r}1.3 \\
0.8\end{array}$ & $\begin{array}{r}-9.5 \\
0.5\end{array}$ & $+\begin{array}{r}0.9 \\
0.9\end{array}$ & $\begin{array}{r}2.4 \\
0.7\end{array}$ & $-\begin{array}{r}0.1 \\
1.0\end{array}$ & $-\begin{array}{r}4.8 \\
0.6\end{array}$ & $\begin{array}{r}2.7 \\
0.8\end{array}$ \\
\hline Epinephrine... & 6 & $\begin{array}{l}0.7 \\
\text { mgm. }\end{array}$ & +21.0 & $+\begin{array}{l}4.8 \\
0.3\end{array}$ & $\mid \begin{array}{r}-14.5 \\
0.01\end{array}$ & +51.7 & $\begin{array}{r}+22.7 \\
0.02\end{array}$ & $\begin{array}{r}+52.4 \\
0.01\end{array}$ & $\begin{array}{c}+26.2 \\
0.05\end{array}$ & -4.0 & +30.4 & $\begin{array}{l}-13.3 \\
0.05\end{array}$ & $\begin{array}{c}+26.0 \\
0.05\end{array}$ & $\begin{array}{r}+42.0 \\
0.01\end{array}$ & -35.1 \\
\hline Ephedrine.. & 6 & $\begin{array}{l}53 \\
\text { mgm. }\end{array}$ & $+\begin{array}{l}9.7 \\
0.02\end{array}$ & $+\begin{array}{c}14.8 \\
0.02\end{array}$ & $+\begin{array}{r}5.2 \\
0.2\end{array}$ & $\begin{array}{r}+27.0 \\
0.5\end{array}$ & $\begin{array}{r}+15.7 \\
0.2\end{array}$ & $\begin{array}{r}+41.2 \\
0.02\end{array}$ & $\begin{array}{c}+32.7 \\
0.05\end{array}$ & $\begin{array}{r}-1.0 \\
0.8\end{array}$ & $+\begin{array}{r}14.2 \\
0.1\end{array}$ & $\begin{array}{r}-8.8 \\
0.1\end{array}$ & $+\underset{0.3}{9.2}$ & $\begin{array}{r}+19.4 \\
0.08\end{array}$ & $\begin{array}{r}-12.9 \\
0.01\end{array}$ \\
\hline Caffeine... & 4 & $\begin{array}{l}0.5 \\
\text { gram }\end{array}$ & $\begin{array}{r}-2.4 \\
0.6\end{array}$ & $\begin{array}{r}-4.0 \\
0.1\end{array}$ & $\begin{array}{r}-3.8 \\
0.1\end{array}$ & $\begin{array}{r}+14.8 \\
0.3\end{array}$ & $\begin{array}{r}+18.1 \\
0.4\end{array}$ & $\begin{array}{r}+9.3 \\
0.5\end{array}$ & $\begin{array}{r}+13.8 \\
0.4\end{array}$ & $\begin{array}{r}-0.8 \\
0.5\end{array}$ & $\begin{array}{r}6.9 \\
0.7\end{array}$ & $\begin{array}{r}-6.1 \\
0.6\end{array}$ & $-\begin{array}{r}4.1 \\
0.4\end{array}$ & $\begin{array}{r}+12.6 \\
0.6\end{array}$ & $\begin{array}{r}-14.3 \\
0.3\end{array}$ \\
\hline Theophylline. . & 7 & $\begin{array}{l}0.48 \\
\text { gram }\end{array}$ & $-\begin{array}{r}1.7 \\
0.6\end{array}$ & $\begin{array}{r}6.8 \\
0.2\end{array}$ & $+\begin{array}{r}7.0 \\
0.1\end{array}$ & $\begin{array}{r}+25.8 \\
0.01\end{array}$ & $\begin{array}{r}29.4 \\
0.01\end{array}$ & $\begin{array}{r}+35.4 \\
0.01\end{array}$ & $\begin{array}{r}+38.0 \\
0.01\end{array}$ & $\begin{array}{r}-0.3 \\
0.9\end{array}$ & $\begin{array}{r}7.8 \\
0.8\end{array}$ & $\begin{array}{r}-12.4 \\
0.1\end{array}$ & $+\begin{array}{r}2.7 \\
0.7\end{array}$ & $\begin{array}{r}+23.8 \\
0.8\end{array}$ & $\begin{array}{r}-18.9 \\
0.05\end{array}$ \\
\hline Carbaminoylcholine.... & 6 & $\begin{array}{l}0.5 \\
\text { mgm. }\end{array}$ & $+\begin{array}{c}7.6 \\
0.01\end{array}$ & $\begin{array}{c}-6.5 \\
0.08\end{array}$ & $-\begin{array}{c}7.2 \\
0.02\end{array}$ & $\begin{array}{r}+12.3 \\
0.1\end{array}$ & $\begin{array}{r}3.7 \\
0.6\end{array}$ & $\begin{array}{r}+4.9 \\
0.5\end{array}$ & $\begin{array}{r}-2.6 \\
0.7\end{array}$ & $\begin{array}{r}-2.0 \\
0.5\end{array}$ & $\begin{array}{r}3.5 \\
0.4\end{array}$ & $\begin{array}{r}-5.5 \\
0.6\end{array}$ & $\begin{array}{r}-0.2 \\
1.0\end{array}$ & $+\begin{array}{l}5.6 \\
0.01\end{array}$ & $\begin{array}{r}-16.6 \\
0.01\end{array}$ \\
\hline Sodium nitrite......... & 7 & $\begin{array}{l}0.13 \\
\text { gram }\end{array}$ & -0.8 & $\begin{array}{r}-13.8 \\
0.01\end{array}$ & $\begin{array}{r}-11.5 \\
0.01\end{array}$ & $\begin{array}{r}3.4 \\
0.8\end{array}$ & $\begin{array}{r}+5.0 \\
0.7\end{array}$ & $\begin{array}{r}-8.5 \\
0.5\end{array}$ & $\begin{array}{r}-6.3 \\
0.4\end{array}$ & $\begin{array}{r}-0.1 \\
1.0\end{array}$ & $\begin{array}{r}5.0 \\
0.1\end{array}$ & $\begin{array}{r}4.9 \\
0.6\end{array}$ & $-\begin{array}{r}4.6 \\
0.3\end{array}$ & $+\begin{array}{r}1.0 \\
0.8\end{array}$ & $\begin{array}{r}-15.4 \\
0.05\end{array}$ \\
\hline Pitreasin.. & 7 & $\begin{array}{l}20 \\
\text { units }\end{array}$ & $-\begin{array}{r}3.7 \\
0.1\end{array}$ & $\begin{array}{r}-3.6 \\
0.8\end{array}$ & $\begin{array}{r}-0.2 \\
1.0\end{array}$ & $-\begin{array}{r}1.8 \\
0.9\end{array}$ & $\begin{array}{r}2.0 \\
0.8\end{array}$ & $\begin{array}{r}-4.5 \\
0.6\end{array}$ & $-\begin{array}{r}1.9 \\
0.9\end{array}$ & $\begin{array}{r}-1.4 \\
0.6\end{array}$ & $\begin{array}{r}3.3 \\
0.5\end{array}$ & $\begin{array}{r}8.7 \\
0.3\end{array}$ & $\begin{array}{r}-0.5 \\
1.0\end{array}$ & $\begin{array}{r}3.9 \\
0.6\end{array}$ & $\begin{array}{r}-1.2 \\
1.0\end{array}$ \\
\hline Quinidine............ & 8 & $\begin{array}{l}1.2 \\
\text { grams }\end{array}$ & $+\begin{array}{c}7.7 \\
0.05\end{array} \mid$ & -1.4 & $+\begin{array}{l}1.2 \\
0.7\end{array}$ & $\begin{array}{r}3.6 \\
0.5\end{array}$ & $\mid$\begin{tabular}{r|}
-9.5 \\
0.05
\end{tabular} & $\begin{array}{r}-4.3 \\
0.6\end{array}$ & $\begin{array}{c}-10.9 \\
0.05\end{array}$ & $\begin{array}{c}-6.7 \\
0.05\end{array}$ & $-\begin{array}{r}3.3 \\
0.3\end{array}$ & $\begin{array}{r}0.1 \\
1.0\end{array}$ & $+\begin{array}{r}5.7 \\
0.4\end{array}$ & $+\begin{array}{r}5.8 \\
0.2\end{array}$ & $\begin{array}{r}3.7 \\
0.6\end{array}$ \\
\hline Morphine (cardiacs)..... & 8 & $\begin{array}{l}19 \\
\text { mgm. }\end{array}$ & $-\begin{array}{r}1.7 \\
0.6\end{array}$ & $-\begin{array}{r}2.7 \\
0.4\end{array}$ & $-\begin{array}{r}2.5 \\
0.1\end{array}$ & -7.3 & $\begin{array}{r}-5.3 \\
0.4\end{array}$ & $\begin{array}{r}-8.7 \\
0.1\end{array}$ & $\begin{array}{r}-8.0 \\
0.5\end{array}$ & $=$ & $-\begin{array}{r}2.3 \\
0.5\end{array}$ & $\begin{array}{r}7.5 \\
0.4\end{array}$ & $\begin{array}{r}-10.0 \\
0.1\end{array}$ & $\begin{array}{r}-10.4 \\
0.01\end{array}$ & $+\begin{array}{r}7.0 \\
0.2\end{array}$ \\
\hline Morphine (non-cardiacs)... & 8 & $\begin{array}{l}14 \\
\text { mgm. }\end{array}$ & $\begin{array}{r}-4.9 \\
0.1\end{array}$ & $\begin{array}{r}-0.1 \\
1.0\end{array}$ & $+\begin{array}{r}1.0 \\
0.8\end{array}$ & $-\begin{array}{r}1.1 \\
0.9\end{array}$ & $\begin{array}{r}4.0 \\
0.6\end{array}$ & $\begin{array}{r}-0.7 \\
1.0\end{array}$ & $\begin{array}{r}4.3 \\
0.6\end{array}$ & $\overline{-}$ & $+\frac{0.4}{1}$ & $\begin{array}{r}4.0 \\
0.7\end{array}$ & -7.7 & $\begin{array}{r}-6.4 \\
0.2\end{array}$ & $\begin{array}{r}3.6 \\
0.8\end{array}$ \\
\hline Strychnine. . & 7 & \begin{tabular}{|l|}
1.8 \\
mgm.
\end{tabular} & $\begin{array}{r}-2.6 \\
0.4\end{array}$ & $-\begin{array}{r}0.2 \\
1.0\end{array}$ & $+\begin{array}{r}0.6 \\
0.2\end{array}$ & -9.0 & $\begin{array}{r}5.0 \\
0.3\end{array}$ & $\begin{array}{r}-10.8 \\
0.1\end{array}$ & $\begin{array}{r}-9.7 \\
0.05\end{array}$ & $\begin{array}{r}-6.3 \\
0.2\end{array}$ & $-\frac{1.6}{0.8}$ & $+\begin{array}{r}11.5 \\
0.1\end{array}$ & $\begin{array}{r}1.8 \\
0.8\end{array}$ & $+\begin{array}{l}3.8 \\
0.7\end{array}$ & $\begin{array}{r}+11.9 \\
0.1\end{array}$ \\
\hline
\end{tabular}

* Mean percentage changes induced by drug action in Roman type

Probabilities of significance of the means, for $P=1$, in italics

In two cases, first given "half," then "full" dosage, the pulse rate first diminished and then returned to its previous level. It is interesting to recall that repeated doses of digitalis, given in acute animal experiments, often cause a primary slowing followed by an increase of heart rate (22).

\section{Effect of atropine on cases receiving digitalis}

In two cardiac cases, Numbers 288 and 306, we estimated the effects of a subcutaneous dose of atropine on patients having an abnormally slow heart rate under digitalis. Case 288 , with auricular fibrillation, was given $0.6 \mathrm{mgm}$. atropine. The pulse rate increased 19 per cent, the heart size diminished slightly and the metabolic rate increased a little. The cardiac output was unchanged (Table II).
Case 306 in normal rhythm received $1.2 \mathrm{mgm}$. of atropine. A marked increase of pulse rate followed but the cardiac output diminished significantly. Pulse pressure diminished in both cases leaving mean blood pressure essentially unchanged.

Obviously the striking effect of atropine is on the pulse rate, the other changes were not constant.

\section{The effect of coupled beats}

Purely by accident, we obtained, after Case 260 had received a large dose of digitalis, one set of estimations while coupled beats had supplanted normal rhythm. A few minutes later normal rhythm returned and a similar set of observations was secured. Our confidence in the validity of the differences in cardiac output found is en- 
hanced by the fact that we always obtained excellent agreement of duplicate estimations in this patient.

During the period of coupling, the pulse rate was but little faster than in the following normal rhythm but the cardiac output was diminished markedly, the metabolic rate was diminished, and the respiratory rate increased. The change in cardiac output during the coupling was of the magnitude which would be present if the normal beats delivered the same amount as before but the extrasystoles contributed almost nothing to the circulation. Apparently this common complication of digitalis action may cause a profound depression of the circulation. It is of interest that the patient insisted he felt as well during the coupling as before or afterward.

\section{Discussion of digitalis action}

That digitalis benefits patients with certain types of heart disease has been known since Withering. The clinical work on this subject has been reviewed recently $(24,25)$. The mechanism underlying this improvement has been debated (26). Most conspicuous in patients with decompensated fibrillating hearts, the improvement was attributed by Mackenzie to the change in rate of beating. Clinicians have usually believed that the improvement secured in patients with exhausted hearts, beating with regular rhythm, resulted from an increased contraction, and a larger output (24). This belief was supported by the results of Cushny's experiments on mammalian hearts with the cardiometer and the myocardiograph (22).

The discovery that digitalis decreased the output of the heart of normal dogs $(20,26)$ was therefore unexpected, as was the opinion that digitalis should be regarded as a cardiac sedative (26). Reduction of cardiac output after digitalis was found in normal men by Burwell, Neighbors and Regen (19) and by Stewart and Cohn (20). We find it also.

Studies upon the effect of these drugs on the output of decompensated hearts have been less concordant. Ringer and Altschule (27) and Lauter and Baumann (28) found an increase in output in weakened hearts, while Kininmonth (29) found increases in some subjects and de- creases in others. Little confidence can be placed in these observations, however, for they were made with methods based on erroneous assumptions. Eppinger, von Papp, and Schwarz (30) and Schwarz and Schimmer (31) using an oxygen method of doubtful accuracy found a decrease of output in cardiac patients with digitalis, while Ewig and Hinsberg (32) with a carbon dioxide method found no change. In contrast, however, Grassmann and Herzog (33) using the acetylene method of Grollman (6) found an increase in most cases when given digitalis. This finding was supported by acute experiments with intravenous injections of strophanthin, in which the cardiac output was deduced by the pulsewave-velocity and blood pressure method of Broemser and Ranke (34).

Stewart and Cohn (20), employing Grollman's method, with which they had found a decrease in normal cases, discovered an increased output associated with digitalis in patients with signs of heart failure but without pulmonary congestion. They suggested that the drug increased the extent of the contraction in both conditions, and that the accompanying decrease in heart size, which led to a lower output from a normal heart, resulted in a larger output from one which had been dilated initially.

Using a slight modification of the same method, Friedman, Clark, Resnik and Harrison (35) found no such consistent increase in minute volume in decompensated subjects. Administration of digitalis gave an increase in some cases, but no change or a decrease in others. The direction of the change could not be correlated with the presence or absence of clinical improvement. They attributed the divergent results of Stewart and Cohn to the failure of these investigators to secure adequate mixing of the respiratory gases, and considered that in their own work this had been avoided by a slight prolongation of the rebreathing time. If this is the explanation, we are left with the impression that slight differences in technique make such great differences in result that our confidence in the accuracy attained is diminished. The difficulties inherent in the application of the gas methods for estimating cardiac output in patients with varying amounts of pulmonary congestion are obvious. But we ac- 

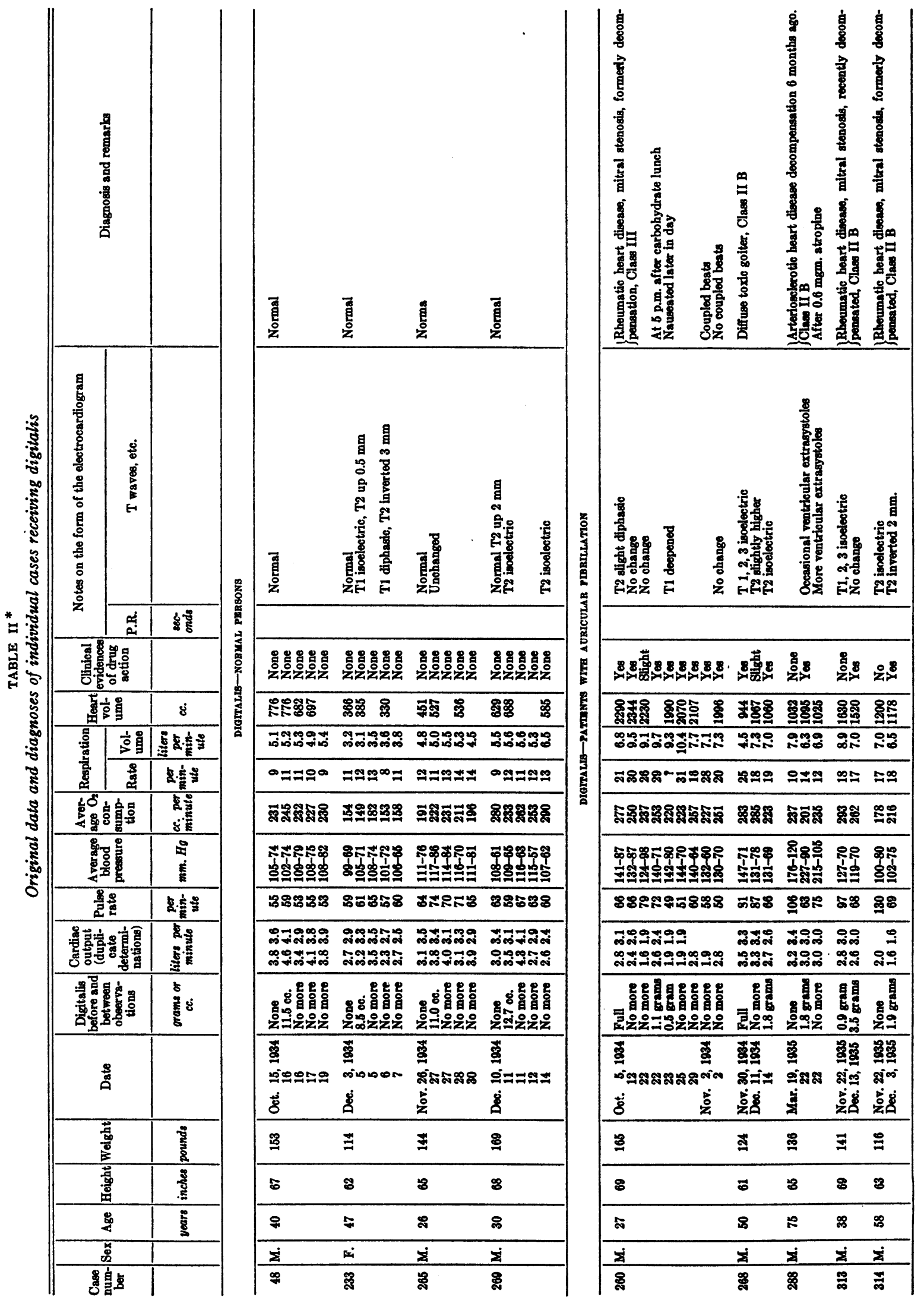
ACTION OF DRUGS UPON THE HEART AND CIRCULATION

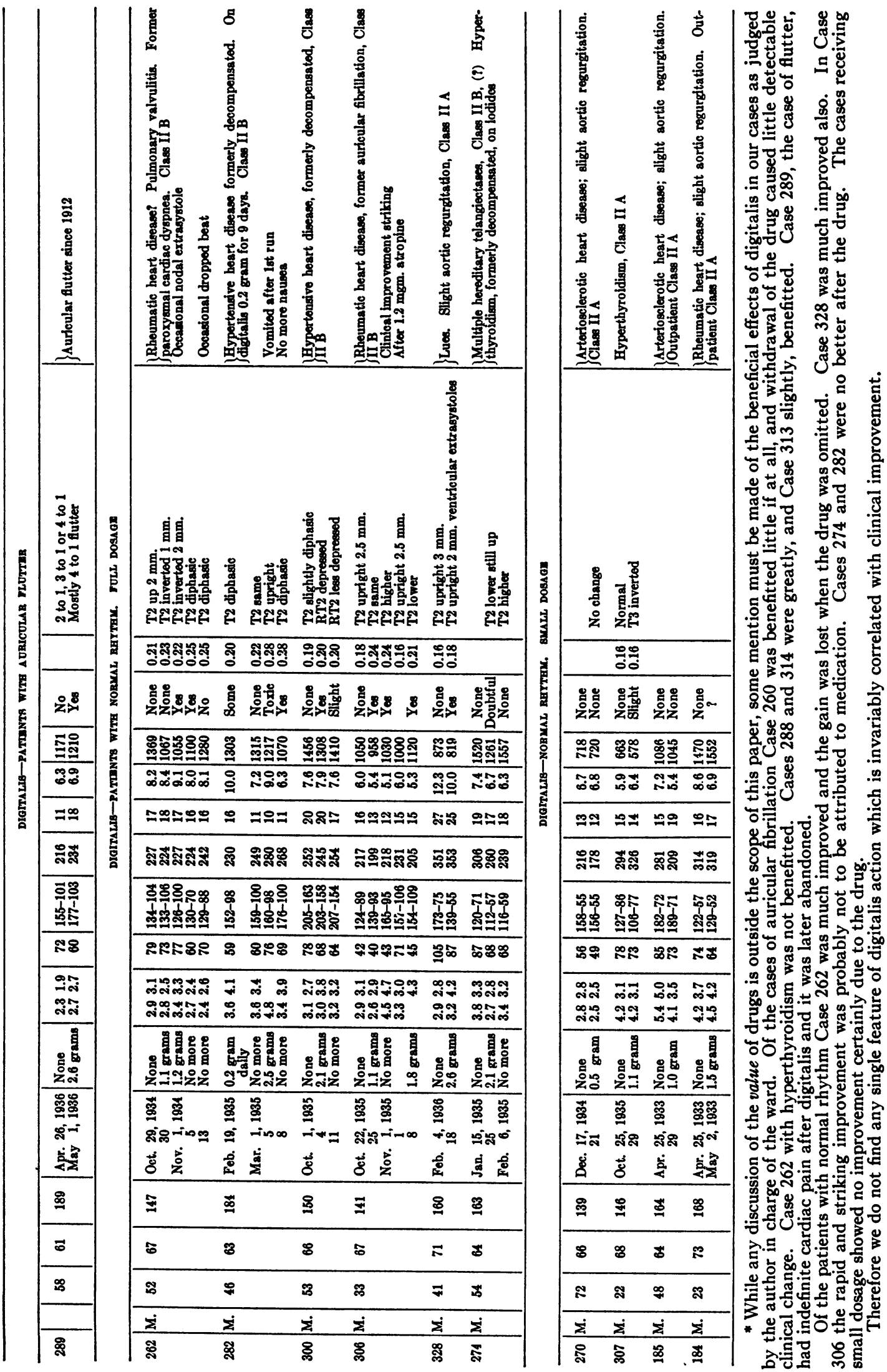


cept these results as the best that can be obtained at present under these conditions.

Therefore one might judge from the literature that digitalis exhibited varying cardiac effects in animal preparations, in normal persons, in patients with heart disease and normal rhythm, and in auricular fibrillation. Our results, viewed superficially, would reveal the same thing, for considering all our subjects as one group, the estimated cardiac output after digitalis is diminished in four, increased in eight, varied in four, and was essentially unchanged in four. A similar diversity of results was found by Harrison and his coworkers in congestive heart failure (21).

But by the application of the conception described on page 802 our results can be unified. Utilizing our definition of stimulation and depression, and plotting the average digitalis effects in Figure 1 and the satisfactory individual cases in Figure 2, we find that digitalis stimulates the heart in every instance, i.e. the heart's work per beat, in proportion to its size, increases. Withdraw the drug and the reverse usually occurs. Those cases in which cardiac output diminished after digitalis also have had a diminution of pulse rate, or of heart size, or of both.

We, therefore, support the classic view that digitalis is a cardiac stimulant, a conclusion drawn many times from the results of clinical observation and animal experiment, and we believe that the apparent divergencies of digitalis action can be unified by this conception.

\section{Epinephrine}

The second group of estimations was made from 20 to 40 minutes after the subcutaneous injection when tremor of extended hands, and changes in either pulse rate or blood pressure were present. The results, Table III, are similar in most respects to those of our predecessors in this field. Somewhat to our surprise the average mean blood pressure failed to rise after adrenalin in our subjects. The systolic pressure rose in 4 of the 6 subjects but the diastolic pressure fell in every instance. The latter is the usual finding (36) so the effect on mean blood pressure is often small.

Our results (Figure 3 and Table III) show a significant increase in pulse rate, metabolic rate, cardiac output, cardiac work, and respiration after the drug. There was also a great diminution of peripheral resistance. Marked stimulation of the heart muscle is indicated by the data illustrated in Figure 1.

The electrocardiograms showed no noteworthy change except in Case 299, who, showing only occasional ventricular extrasystoles before the drug, developed short periods of bigeminal rhythm, the extrasystoles replacing every second beat.

The usual effects of epinephrine increasing metabolic rate, systolic blood pressure and pulse rate are well known. Euler and Liljestrand (37) first demonstrated effect on cardiac output on two normal subjects. Field and Bock obtained a similar result (38). Lauber and Brauch (39) secured evidence of a similar effect on 3 patients at the height of action, after a small dose, as 0.01 mgm., given intravenously. The latter authors employed Broemser and Ranke's method (34) in which cardiac output is deduced from the blood pressure and pulse wave velocity. This method has been criticized (4), and we have had no experience which permits us to evaluate its results.

It should be emphasized that the effects of epinephrine on heart and circulation far overbalanced the blood pressure effects on our subjects. Indeed, despite the blanching around the site of injection seen in all our subjects, and the facial pallor seen in some, the peripheral resistance markedly diminished in every case, and one is forced to conclude that vessels dilated at some location. Clough deduced this from the fall of diastolic pressure (40) and Grollman points out the same implication in Euler and Liljestrand's data (6).

It seems reasonable to suppose that local vasoconstriction at the site of injection, due to the high concentration of drug at that spot, so impedes absorption that the minute amounts of drug reaching the general circulation dilate vessels as do extremely minute doses injected intravenously in animal experiments. Reflex vasodilatation from increased pressure due to the cardiac stimulation may be a factor also.

\section{Ephedrine}

Changes in blood pressure allowed us to identify clearly the height of action in most instances 
TABLE III

Original data and diagnoses of individual cases

\begin{tabular}{|c|c|c|c|c|c|c|c|c|c|c|c|c|c|c|}
\hline \multirow{3}{*}{$\begin{array}{c}\text { Case } \\
\text { num- } \\
\text { ber }\end{array}$} & \multirow{3}{*}{ Sex } & \multirow{3}{*}{$\begin{array}{l}\text { Age } \\
\text { years }\end{array}$} & \multirow{3}{*}{\begin{tabular}{|l} 
Height \\
inches
\end{tabular}} & \multirow{3}{*}{$\begin{array}{l}\text { Weight } \\
\text { pounds }\end{array}$} & \multirow{2}{*}{\multicolumn{2}{|c|}{$\begin{array}{c}\text { Cardiac } \\
\text { output } \\
\text { (dupli- } \\
\text { cate } \\
\text { deter- } \\
\text { mina- } \\
\text { tions) }\end{array}$}} & \multirow{2}{*}{$\begin{array}{c}\text { Pulse } \\
\text { rate }\end{array}$} & \multirow{2}{*}{$\begin{array}{l}\text { Average } \\
\text { blood } \\
\text { pressure }\end{array}$} & \multirow{2}{*}{$\begin{array}{c}\text { Aver- } \\
\text { age } \mathrm{O}_{2} \\
\text { con- } \\
\text { sump- } \\
\text { tion }\end{array}$} & \multicolumn{2}{|c|}{ Respiration } & \multirow{2}{*}{$\begin{array}{c}\text { Heart } \\
\text { vol- } \\
\text { ume }\end{array}$} & \multirow{2}{*}{ Dose } & \multirow{2}{*}{ Diagnosis and remarks } \\
\hline & & & & & & & & & & Rate & $\begin{array}{l}\text { Vol- } \\
\text { ume }\end{array}$ & & & \\
\hline & & & & & $\begin{array}{l}\text { liter } \\
\text { per } \\
\text { minu }\end{array}$ & $\begin{array}{l}\text { ers } \\
\text { er } \\
\text { inte }\end{array}$ & $\begin{array}{c}\text { per } \\
\text { min- } \\
\text { ute }\end{array}$ & mm. Ho & $\begin{array}{c}\text { cc.per } \\
\text { min- } \\
\text { ute }\end{array}$ & $\begin{array}{c}\text { per } \\
\text { min- } \\
\text { ute }\end{array}$ & $\begin{array}{c}\text { liters } \\
\text { per } \\
\text { minute }\end{array}$ & ce. & & \\
\hline \multicolumn{15}{|c|}{ EPINEPHRINE } \\
\hline $\begin{array}{r}1 \\
274 \\
276 \\
299 \\
326 \\
333\end{array}$ & $\begin{array}{l}\text { M. } \\
\text { M. } \\
\text { M. } \\
\text { M. } \\
\text { M. } \\
\text { M. }\end{array}$ & $\begin{array}{l}62 \\
54 \\
47 \\
52 \\
50 \\
52\end{array}$ & $\begin{array}{l}73 \\
64 \\
71 \\
72 \\
62 \\
65\end{array}$ & $\begin{array}{r}168 \\
163 \\
165 \\
162 \\
156 \\
152\end{array}$ & $\begin{array}{l}3.3 \\
4.3 \\
3.4 \\
5.3 \\
3.3 \\
6.1 \\
4.0 \\
5.6 \\
3.4 \\
4.5 \\
3.0 \\
6.3\end{array}$ & $\begin{array}{l}3.2 \\
4.2 \\
3.1 \\
5.4 \\
3.7 \\
5.5 \\
3.6 \\
5.7 \\
4.1 \\
6.0\end{array}$ & $\begin{array}{r}56 \\
62 \\
68 \\
67 \\
78 \\
104 \\
92 \\
110 \\
64 \\
82 \\
57 \\
78\end{array}$ & $\begin{array}{l}168-75 \\
155-58 \\
116-59 \\
130-53 \\
114-65 \\
112-57 \\
120-105 \\
129-84 \\
136-87 \\
155-83 \\
118-80 \\
128-65\end{array}$ & $\begin{array}{l}282 \\
308 \\
239 \\
312 \\
213 \\
310 \\
379 \\
543 \\
248 \\
304 \\
176 \\
230\end{array}$ & $\begin{array}{r}18 \\
18 \\
9 \\
14 \\
20 \\
27 \\
11 \\
15 \\
12 \\
14\end{array}$ & \begin{tabular}{r|}
$\mathbf{8 . 1}$ \\
$\mathbf{9 . 6}$ \\
$\mathbf{6 . 4}$ \\
$\mathbf{8 . 8}$ \\
$\mathbf{5 . 3}$ \\
8.9 \\
$\mathbf{8 . 9}$ \\
$\mathbf{1 1 . 8}$ \\
$\mathbf{1 6 . 5}$ \\
$\mathbf{5 . 4}$ \\
$\mathbf{8 . 0}$ \\
4.3 \\
$\mathbf{5 . 9}$
\end{tabular} & \begin{tabular}{|r|}
1587 \\
1425 \\
564 \\
554 \\
1157 \\
1150 \\
815 \\
690 \\
666
\end{tabular} & \begin{tabular}{c|} 
mom. \\
0.5 \\
0.45 \\
0.8 \\
0.5 \\
1.0 \\
0.75
\end{tabular} & $\begin{array}{l}\text { Diabetes mellitus, peripheral vascular disease } \\
\text { Arteriosclerosis } \\
\text { Multiple hereditary telangiectases. Congestive failure } 6 \text { months } \\
\text { before } \\
\text { Neurocirculatory asthenis } \\
\text { Hyperthyroidism } \\
\text { Myxedema under thyroid medication } \\
\text { Arteriosclerotic heart disease. Angina pectorls } \\
\text { Psychoneurosis }\end{array}$ \\
\hline \multicolumn{15}{|c|}{ EPHDDRINE } \\
\hline $\begin{array}{l}233 \\
258 \\
263 \\
265 \\
269 \\
332\end{array}$ & $\begin{array}{l}\text { F. } \\
\text { M. } \\
\text { M. } \\
\text { M. } \\
\text { M. } \\
\text { M. }\end{array}$ & $\begin{array}{l}47 \\
50 \\
43 \\
26 \\
30 \\
62\end{array}$ & $\begin{array}{l}62 \\
67 \\
68 \\
65 \\
68 \\
65\end{array}$ & $\begin{array}{l}114 \\
130 \\
140 \\
144 \\
169 \\
189\end{array}$ & $\begin{array}{l}2.7 \\
3.7 \\
3.4 \\
5.1 \\
4.1 \\
3.4 \\
3.1 \\
3.0 \\
3.0 \\
4.9 \\
2.0 \\
2.8\end{array}$ & $\begin{array}{l}2.9 \\
3.5 \\
3.1 \\
4.6 \\
3.2 \\
3.9 \\
3.5 \\
4.5 \\
3.4 \\
4.5 \\
3.0 \\
3.2\end{array}$ & $\begin{array}{l}59 \\
67 \\
62 \\
68 \\
58 \\
61 \\
64 \\
72 \\
63 \\
63 \\
70 \\
83\end{array}$ & $\begin{array}{r}99-70 \\
115-73 \\
96-79 \\
128-89 \\
102-79 \\
112-79 \\
111-76 \\
118-77 \\
108-61 \\
115-70 \\
116-69 \\
135-68\end{array}$ & $\begin{array}{l}154 \\
158 \\
121 \\
177 \\
223 \\
232 \\
191 \\
209 \\
280 \\
322 \\
264 \\
287\end{array}$ & $\begin{array}{r}11 \\
14 \\
17 \\
17 \\
7 \\
9 \\
12 \\
15 \\
9 \\
7 \\
22 \\
23\end{array}$ & $\begin{array}{l}\mathbf{3 . 2} \\
\mathbf{3 . 7} \\
\mathbf{3 . 5} \\
\mathbf{3 . 8} \\
\mathbf{5 . 1} \\
\mathbf{5 . 8} \\
\mathbf{4 . 8} \\
\mathbf{5 . 4} \\
\mathbf{5 . 5} \\
\mathbf{7 . 9} \\
\mathbf{7 . 2} \\
\mathbf{8 . 8}\end{array}$ & $\begin{array}{l}509 \\
468 \\
451 \\
456 \\
629 \\
750 \\
781\end{array}$ & $\begin{array}{l}m g m . \\
50 \\
50 \\
50 \\
50 \\
50 \\
67.5\end{array}$ & $\begin{array}{l}\text { Normal } \\
\text { (?) Myxedems } \\
\text { (?) Neurasthenia } \\
\text { Normsl } \\
\text { Normal } \\
\text { Gastro-intestinal influenza } \\
\text { Convalescent }\end{array}$ \\
\hline \multicolumn{15}{|c|}{ CAFreng } \\
\hline $\begin{array}{l}281 \\
282 \\
283\end{array}$ & $\begin{array}{c}\text { M. } \\
\text { M. } \\
\text { F. } \\
\text { M. }\end{array}$ & $\begin{array}{l}23 \\
46 \\
32 \\
37\end{array}$ & $\begin{array}{l}66 \\
63 \\
64 \\
70\end{array}$ & \begin{tabular}{r|}
145 \\
184 \\
157 \\
191
\end{tabular} & $\begin{array}{l}4.3 \\
6.0 \\
3.6 \\
3.6 \\
3.5 \\
5.5 \\
5.3 \\
5.1\end{array}$ & $\begin{array}{l}3.9 \\
5.6 \\
4.1 \\
4.1 \\
4.2 \\
4.3 \\
4.5 \\
3.9\end{array}$ & $\begin{array}{l}73 \\
65 \\
59 \\
63 \\
93 \\
92 \\
67 \\
63\end{array}$ & $\begin{array}{l}138-49 \\
129-46 \\
152-98 \\
145-91 \\
117-75 \\
115-74 \\
125-77 \\
123-76\end{array}$ & $\begin{array}{l}259 \\
262 \\
230 \\
235 \\
168 \\
239 \\
268 \\
220\end{array}$ & $\begin{array}{r}10 \\
10 \\
16 \\
14 \\
9 \\
9 \\
14 \\
14\end{array}$ & $\begin{array}{r}5.1 \\
5.4 \\
10.0 \\
9.4 \\
4.1 \\
7.1 \\
7.5 \\
5.8\end{array}$ & $\begin{array}{r}920 \\
894 \\
1303 \\
1326 \\
545 \\
534 \\
772 \\
772\end{array}$ & $\begin{array}{r}\text { orams } \\
.5 \\
.5 \\
.5 \\
.5 \\
\end{array}$ & $\begin{array}{l}\text { Post-encephalitis. Rheumatic heart disease. Aortic regurgita- } \\
\text { tion. Never decompensated, (?) mitral valvulitis } \\
\text { Hypertensive heart disease. Just out of } 2 \mathrm{~d} \text { decompensation. } \\
\text { On digitalis } \\
\text { Syphilis. Psychoneurosis, (?) neurociroulatory asthenis } \\
\text { Psychoneurosis. Atypical constant precordial pain }\end{array}$ \\
\hline \multicolumn{15}{|c|}{ TAEOPHTLUNE ETHYLENEDUMINE } \\
\hline $\begin{array}{l}303 \\
306 \\
307 \\
308 \\
309 \\
317\end{array}$ & $\begin{array}{l}\text { M. } \\
\text { M. } \\
\text { M. } \\
\text { M. } \\
\text { M. } \\
\text { M. } \\
\text { M. }\end{array}$ & $\begin{array}{l}16 \\
33 \\
22 \\
37 \\
50 \\
47 \\
57\end{array}$ & $\begin{array}{l}68 \\
67 \\
68 \\
68 \\
70 \\
67 \\
66\end{array}$ & \begin{tabular}{r|}
129 \\
141 \\
146 \\
129 \\
136 \\
159 \\
116
\end{tabular} & $\begin{array}{l}2.9 \\
4.8 \\
4.9 \\
4.2 \\
4.9 \\
3.2 \\
3.0 \\
2.5 \\
2.6 \\
3.1 \\
3.4 \\
2.0 \\
2.1\end{array}$ & $\begin{array}{l}3.2 \\
3.9 \\
1.3 \\
6.2 \\
3.1 \\
3.7 \\
2.6 \\
3.3 \\
2.6 \\
2.8 \\
2.3 \\
3.5 \\
1.5 \\
3.3\end{array}$ & \begin{tabular}{|r}
109 \\
100 \\
45 \\
50 \\
73 \\
78 \\
85 \\
76 \\
56 \\
52 \\
91 \\
88 \\
54 \\
53
\end{tabular} & $\begin{array}{c}123-75 \\
118-82 \\
155-108 \\
171-118 \\
106-77 \\
105-77 \\
100-74 \\
97-75 \\
88-62 \\
107-75 \\
148-117 \\
158-130 \\
117-67 \\
137-66\end{array}$ & $\begin{array}{l}247 \\
245 \\
197 \\
253 \\
326 \\
291 \\
211 \\
243 \\
201 \\
219 \\
224 \\
238 \\
178 \\
201\end{array}$ & $\begin{array}{l}23 \\
22 \\
15 \\
20 \\
14 \\
13 \\
19 \\
18 \\
10 \\
10 \\
17 \\
16 \\
17 \\
17\end{array}$ & \begin{tabular}{|r|}
7.1 \\
7.5 \\
5.3 \\
10.3 \\
6.4 \\
6.0 \\
6.8 \\
5.8 \\
6.6 \\
4.8 \\
5.4 \\
5.8 \\
6.3 \\
5.1 \\
6.0
\end{tabular} & $\begin{array}{r}373 \\
412 \\
1120 \\
1055 \\
578 \\
550 \\
608 \\
614 \\
571 \\
565 \\
680 \\
650 \\
528 \\
542\end{array}$ & \begin{tabular}{|r|} 
grams \\
0.48 \\
0.48 \\
0.48 \\
0.48 \\
0.48 \\
0.48 \\
0.48
\end{tabular} & $\begin{array}{l}\text { (?) rheumatic fever. No known cardiac involvement } \\
\text { Advanced rheumatic heart disease. Paroxysm of auricular fibril- } \\
\text { lation. Now normal rhythm. Fully divitalized } \\
\text { Hyperthyrnidism. Has received f caleulated dose digitalis } \\
\text { Angina pectoris. Xanthomatosis } \\
\text { Low backstrain. Possibly neurocirculatory asthenia. } \\
\text { Angina pectoris } \\
\text { Angina pectoris } \\
\text { (?) Duodenal ulcer }\end{array}$ \\
\hline \multicolumn{15}{|c|}{ CARBAMINOTLCHOLINE } \\
\hline $\begin{array}{l}271 \\
277 \\
315 \\
323 \\
324 \\
327\end{array}$ & $\begin{array}{l}\text { M. } \\
\text { M. } \\
\text { M. } \\
\text { M. } \\
\text { M. } \\
\text { M. }\end{array}$ & $\begin{array}{l}39 \\
44 \\
27 \\
36 \\
30 \\
60\end{array}$ & $\begin{array}{l}63 \\
68 \\
60 \\
60 \\
74 \\
66\end{array}$ & $\begin{array}{l}114 \\
153 \\
166 \\
169 \\
182 \\
131\end{array}$ & $\begin{array}{l}2.9 \\
3.9 \\
3.0 \\
3.0 \\
3.4 \\
4.3 \\
3.0 \\
3.1 \\
4.3 \\
3.7 \\
2.1 \\
3.2\end{array}$ & $\begin{array}{l}3.4 \\
3.8 \\
2.9 \\
3.0 \\
3.1 \\
3.3 \\
2.9 \\
3.8 \\
5.0 \\
4.0 \\
2.5 \\
2.9\end{array}$ & $\begin{array}{l}\mathbf{7 3} \\
82 \\
63 \\
71 \\
78 \\
80 \\
80 \\
52 \\
58 \\
73 \\
75 \\
64 \\
68\end{array}$ & $\begin{array}{r}103-69 \\
87-61 \\
223-127 \\
205-122 \\
125-90 \\
112-86 \\
94-65 \\
93-64 \\
113-71 \\
113-61 \\
181-87 \\
174-81\end{array}$ & $\begin{array}{l}226 \\
227 \\
214 \\
235 \\
285 \\
312 \\
230 \\
254 \\
308 \\
313 \\
232 \\
208\end{array}$ & $\begin{array}{r}7 \\
7 \\
15 \\
15 \\
17 \\
18 \\
15 \\
15 \\
15 \\
14 \\
14 \\
14\end{array}$ & $\begin{array}{l}\mathbf{5 . 5} \\
\mathbf{6 . 0} \\
\mathbf{5 . 9} \\
\mathbf{5 . 0} \\
\mathbf{7 . 1} \\
\mathbf{7 . 5} \\
\mathbf{5 . 8} \\
\mathbf{6 . 0} \\
\mathbf{8 . 4} \\
\mathbf{8 . 9} \\
\mathbf{5 . 2} \\
\mathbf{5 . 5}\end{array}$ & $\begin{array}{l}579 \\
555 \\
558 \\
612 \\
755 \\
748 \\
656 \\
656 \\
667 \\
621 \\
720 \\
650\end{array}$ & $\begin{array}{l}\text { mom. } \\
0.5 \\
0.4 \\
0.6 \\
0.6 \\
0.6 \\
0.4\end{array}$ & $\begin{array}{l}\text { Thromboangiitis obliterans } \\
\text { Arteriolar nephrosclerosis } \\
\text { Headache-no cause found } \\
\text { Thrombosngiitis obliterans } \\
\text { Thromboangiitis obliterans } \\
\text { Arteriosclerotic peripheral vascular disease }\end{array}$ \\
\hline
\end{tabular}


TABLE III-Continued

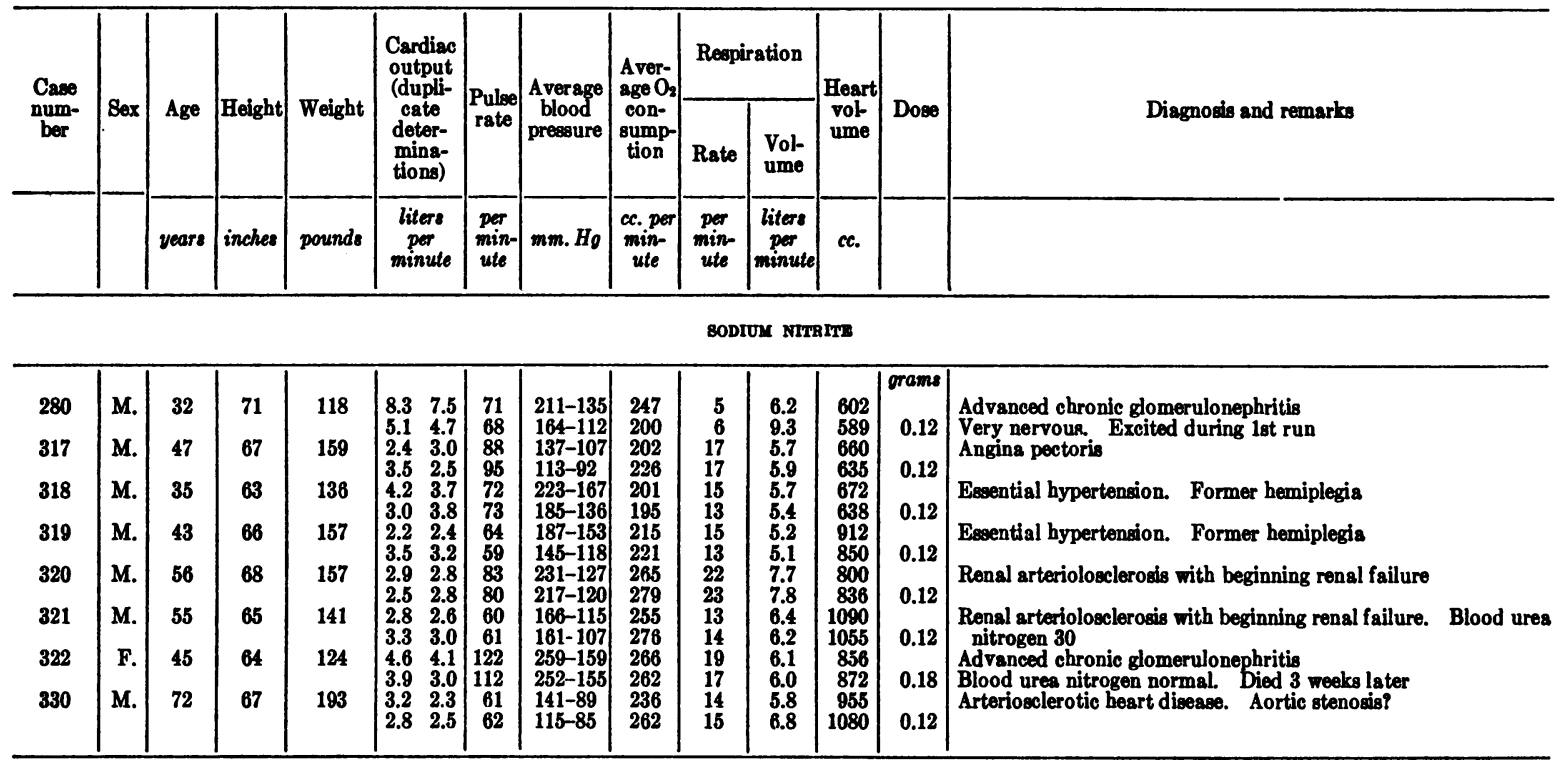

NITROGLYCERINE

\begin{tabular}{|c|c|c|c|c|c|c|c|c|c|c|c|}
\hline $\begin{array}{l}1 \\
2\end{array}$ & $\begin{array}{l}\text { M. } \\
\text { M. }\end{array}$ & $\begin{array}{l}62 \\
63\end{array}$ & $\begin{array}{l}73 \\
73\end{array}$ & $\begin{array}{l}168 \\
170\end{array}$ & $\begin{array}{ll}1.9 & \\
3.9 & 3.1 \\
1.7 & \\
2 . & 3.9\end{array}$ & $\begin{array}{l}54 \\
71 \\
78\end{array}$ & $\begin{array}{r}145-65 \\
114-68 \\
195-95 \\
190-97\end{array}$ & $\begin{array}{l}221 \\
227 \\
195 \\
275\end{array}$ & $\begin{array}{r}6.9 \\
12.1 \\
6.4\end{array}$ & $\begin{array}{c}m g m . \\
1.2\end{array}$ & $\begin{array}{l}\text { Diabetes mellitus. Peripheral vascular disease } \\
\text { Arteriosclerosis } \\
\text { Essential hypertension. Left hemiplegia }\end{array}$ \\
\hline
\end{tabular}

PITRzssin

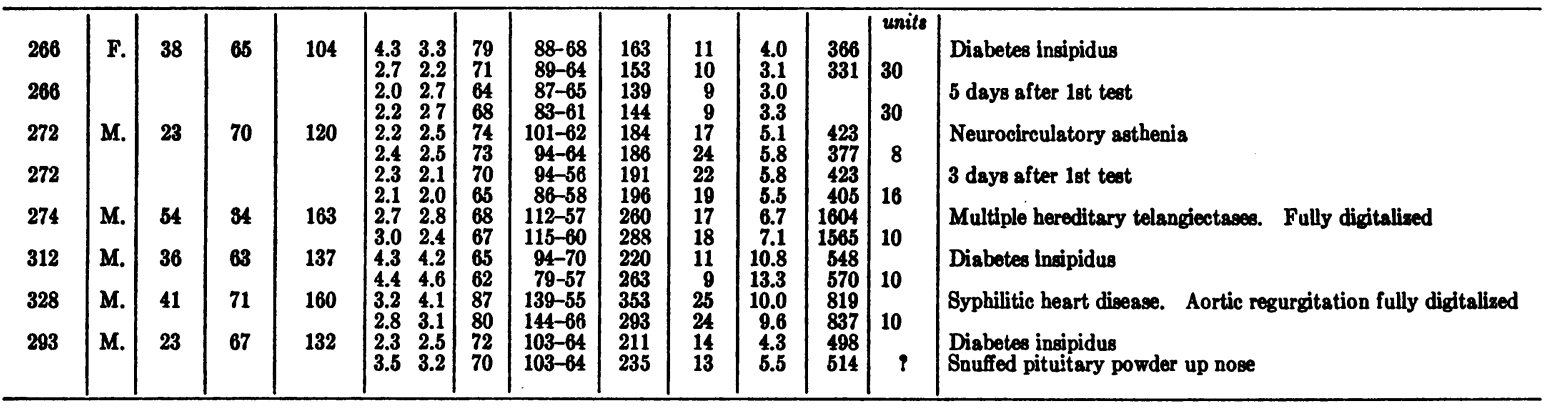

QUNIDINE

\begin{tabular}{|c|c|c|c|c|c|c|c|c|c|c|c|c|c|}
\hline & & & & & \multirow{10}{*}{$\begin{array}{ll}2.8 & 3.0 \\
2.4 & 2.6 \\
2.5 & 2.0 \\
2.8 & 2.8 \\
3.7 & 3.3 \\
3.9 & 3.6 \\
2.2 & 2.3 \\
2.0 & 1.8 \\
3.6 & 3.4 \\
3.1 & 3.5 \\
3.4 & 3.9 \\
3.5 & 3.5 \\
3.8 & 3.9 \\
4.5 & 3.3 \\
4.1 & 4.1 \\
3.6 & 3.0\end{array}$} & \multirow{10}{*}{$\begin{array}{l}66 \\
71 \\
79 \\
93 \\
87 \\
88 \\
61 \\
55 \\
60 \\
70 \\
69 \\
72 \\
86 \\
95 \\
97 \\
110\end{array}$} & \multirow{10}{*}{$\begin{array}{c}141-87 \\
141-95 \\
99-52 \\
102-57 \\
120-71 \\
107-64 \\
137-96 \\
137-97 \\
160-100 \\
16-107 \\
176-100 \\
141-90 \\
196-133 \\
200-137 \\
110-70 \\
114-69\end{array}$} & \multirow{10}{*}{$\begin{array}{l}277 \\
269 \\
193 \\
199 \\
306 \\
309 \\
145 \\
124 \\
249 \\
244 \\
268 \\
232 \\
182 \\
189 \\
187 \\
183\end{array}$} & \multirow{10}{*}{$\begin{array}{l}21 \\
30 \\
21 \\
22 \\
19 \\
20 \\
12 \\
14 \\
11 \\
99 \\
11 \\
11 \\
16 \\
16 \\
18 \\
17\end{array}$} & \multirow{10}{*}{$\begin{array}{l}6.8 \\
8.0 \\
5.5 \\
6.2 \\
7.4 \\
8.0 \\
3.4 \\
3.2 \\
7.2 \\
7.0 \\
6.3 \\
6.6 \\
4.4 \\
4.8 \\
4.9 \\
5.1\end{array}$} & \multirow{10}{*}{$\begin{array}{r}2290 \\
2280 \\
469 \\
424 \\
1834 \\
1640 \\
715 \\
661 \\
1315 \\
1336 \\
1070 \\
1045 \\
5511 \\
460 \\
454 \\
396\end{array}$} & \multirow{10}{*}{$\begin{array}{c}\text { grams } \\
1.0 \\
1.0 \\
1.0 \\
0.6 \\
2.0 \\
2.0 \\
1.4 \\
0.4\end{array}$} & \multirow{10}{*}{$\begin{array}{l}\text { Rheumatic heart disease. Advanced valvulitis. Auricular fi- } \\
\text { brillation. Formerly decompensated. Fully digitalized } \\
\text { Neurocirculatory asthenia } \\
\text { Multiple heriditary telangiectases. Decompensated } 5 \text { months } \\
\text { before. No digitalis } \\
\text { Rheumatic heart disease; mitral stenosis; auricular fibrillation } \\
\text { digitalised } \\
\text { Hypertensive heart disease. Formerly twice decompensated. } \\
\text { No digitalis } \\
7 \text { days after previous test. No digitalis } \\
\text { Improved clinically } \\
\text { Arteriolar nephroselerosis. Nausea and vomiting soon after } \\
\text { post-drug run } \\
\text { Neurocirculatory asthenia }\end{array}$} \\
\hline 260 & M. & 27 & 69 & & & & & & & & & & \\
\hline 274 & M. & 54 & 64 & 163 & & & & & & & & & \\
\hline & & & & & & & & & & & & & \\
\hline 275 & F. & 38 & 60 & 112 & & & & & & & & & \\
\hline 282 & M. & 46 & 63 & 184 & & & & & & & & & \\
\hline 282 & & & & & & & & & & & & & \\
\hline 285 & F. & 32 & 60 & 127 & & & & & & & & & \\
\hline 287 & F. & 34 & 63 & 110 & & & & & & & & & \\
\hline & & & & & & & & & & & & & \\
\hline
\end{tabular}


TABLE III-Continued

\begin{tabular}{|c|c|c|c|c|c|c|c|c|c|c|c|c|c|}
\hline \multirow{3}{*}{$\begin{array}{l}\text { Case } \\
\text { num- } \\
\text { ber }\end{array}$} & \multirow{3}{*}{ Sex } & \multirow{2}{*}{ Age } & \multirow{2}{*}{ Height } & \multirow{2}{*}{ Weight } & \multirow{2}{*}{$\begin{array}{c}\text { Cardiac } \\
\text { output } \\
\text { (dupli- } \\
\text { cate } \\
\text { deter- } \\
\text { mina- } \\
\text { tions) }\end{array}$} & \multirow{2}{*}{$\begin{array}{l}\text { Pulse } \\
\text { rate }\end{array}$} & \multirow{2}{*}{$\begin{array}{c}\text { Average } \\
\text { blood } \\
\text { pressure }\end{array}$} & \multirow{2}{*}{$\begin{array}{c}\text { Aver- } \\
\text { age } \mathrm{O}_{2} \\
\text { con- } \\
\text { sump- } \\
\text { tion- }\end{array}$} & \multicolumn{2}{|c|}{ Respiration } & \multirow{2}{*}{$\begin{array}{c}\text { Heart } \\
\text { vol- } \\
\text { ume }\end{array}$} & \multirow{2}{*}{ Dose } & \multirow{2}{*}{ Diagnosis and remarks } \\
\hline & & & & & & & & & Rate & $\begin{array}{l}\text { Vol- } \\
\text { ume }\end{array}$ & & & \\
\hline & & years & inches & pounds & $\begin{array}{c}\text { liters } \\
\text { per } \\
\text { minute }\end{array}$ & $\begin{array}{c}\text { per } \\
\text { min- } \\
\text { ute }\end{array}$ & $m m . H g$ & $\begin{array}{c}\text { cc.per } \\
\text { min- } \\
\text { ute }\end{array}$ & $\underset{\substack{\text { per } \\
\text { ute }}}{ }$ & $\begin{array}{c}\text { liters } \\
\text { per } \\
\text { minute }\end{array}$ & 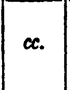 & & \\
\hline \multicolumn{14}{|c|}{ MORPHINI (NON-CARDLAC CASHS) } \\
\hline $\begin{array}{c}239 \\
240 \\
241 \\
4-3-34 \\
241 \\
4-10-34 \\
242 \\
243 \\
244\end{array}$ & $\begin{array}{l}\text { M. } \\
\text { M. } \\
\text { M. } \\
\text { M. } \\
\text { M. } \\
\text { M. } \\
\text { F. }\end{array}$ & $\begin{array}{l}17 \\
58 \\
24 \\
24 \\
29 \\
35 \\
35\end{array}$ & $\begin{array}{l}67 \\
66 \\
64 \\
64 \\
72 \\
68 \\
63\end{array}$ & $\begin{array}{l}115 \\
139 \\
121 \\
121 \\
163 \\
131 \\
117\end{array}$ & $\begin{array}{ll}5.2 & 4.4 \\
3.7 & 3.3 \\
3.5 & 3.8 \\
3.2 & 3.2 \\
3.7 & 3.5 \\
4.7 & 4.4 \\
3.8 & 4.4 \\
3.1 & 3.8 \\
4.7 & 5.1 \\
5.4 & 5.0 \\
4.4 & 3.7 \\
3.9 & 4.6 \\
4.0 & 4.4 \\
4.1 & 4.1\end{array}$ & $\begin{array}{l}94 \\
81 \\
63 \\
60 \\
83 \\
76 \\
72 \\
75 \\
82 \\
82 \\
68 \\
62 \\
72 \\
69\end{array}$ & $\begin{array}{r}124-80 \\
121-76 \\
100-92 \\
96-84 \\
106-78 \\
105-84 \\
99-77 \\
107-84 \\
109-92 \\
110-91 \\
110-95 \\
112-95 \\
104-70 \\
100-75\end{array}$ & $\begin{array}{l}241 \\
235 \\
136 \\
160 \\
204 \\
222 \\
228 \\
248 \\
270 \\
231 \\
213 \\
191 \\
182 \\
173\end{array}$ & $\begin{array}{l}20 \\
18 \\
14 \\
13 \\
17 \\
17 \\
17 \\
15 \\
11 \\
11 \\
13 \\
11 \\
19 \\
16\end{array}$ & $\begin{array}{l}6.5 \\
5.2 \\
3.7 \\
4.3 \\
5.2 \\
4.9 \\
4.9 \\
4.7 \\
5.5 \\
5.4 \\
4.9 \\
3.8 \\
5.3 \\
4.7\end{array}$ & $\begin{array}{l}567 \\
498 \\
498\end{array}$ & $\begin{array}{l}\text { mom. } \\
10 \\
15 \\
15 \\
15 \\
15 \\
15 \\
15\end{array}$ & $\begin{array}{l}\text { Typhoid fever convalescent } \\
\text { Duodenitis } \\
\text { Arthritis, colitis } \\
\text { Arthritis, colitis } \\
\text { Cbronic colitis } \\
\text { Gastric neurosis } \\
\text { Psychoneurosis }\end{array}$ \\
\hline
\end{tabular}

MORPHINE (CARDIAC CASRB)

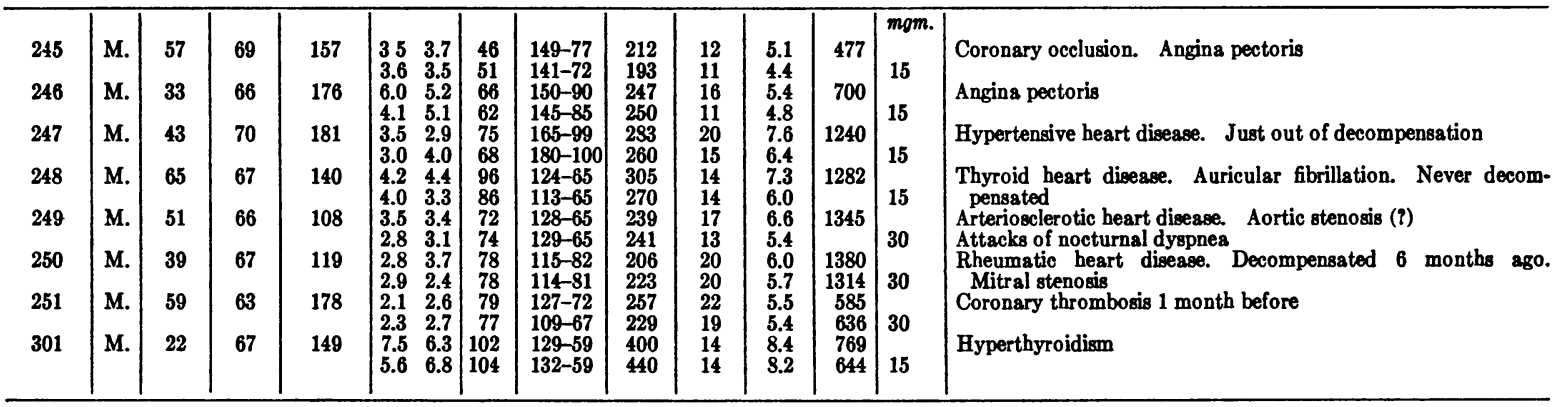

BTRYCHNINE

\begin{tabular}{|c|c|c|c|c|c|c|c|c|c|c|c|c|c|c|}
\hline & & & & & \multirow{10}{*}{\multicolumn{2}{|c|}{$\begin{array}{ll}2.0 & 1.4 \\
1.5 & 1.7 \\
2.5 & 2.9 \\
2.5 & 2.5 \\
5.6 & 5.1 \\
1.0 & 3.6 \\
4.8 & 4.1 \\
4.7 & 3.5 \\
3.0 & 2.6 \\
3.0 & 3.1 \\
4.9 & 4.8 \\
4.5 & 4.2 \\
6.5 & 5.7 \\
5.0 & 4.1 \\
3.3 & 2.6 \\
2.7 & 2.3\end{array}$}} & \multirow{10}{*}{$\begin{array}{l}60 \\
60 \\
55 \\
54 \\
72 \\
64 \\
52 \\
52 \\
54 \\
55 \\
64 \\
59 \\
98 \\
90 \\
80 \\
80\end{array}$} & \multirow{10}{*}{$\begin{array}{r}103-69 \\
95-62 \\
119-71 \\
122-72 \\
116-68 \\
120-64 \\
127-24 \\
135-25 \\
133-83 \\
132-76 \\
100-67 \\
98-66 \\
109-85 \\
110-85 \\
160-115 \\
152-110\end{array}$} & \multirow{10}{*}{$\begin{array}{l}162 \\
143 \\
205 \\
165 \\
222 \\
208 \\
250 \\
278 \\
199 \\
217 \\
235 \\
256 \\
258 \\
220 \\
287 \\
284\end{array}$} & \multirow{10}{*}{$\begin{array}{r}20 \\
23 \\
20 \\
15 \\
11 \\
10 \\
13 \\
13 \\
14 \\
14 \\
8 \\
8 \\
20 \\
19 \\
12 \\
15\end{array}$} & \multirow{10}{*}{$\begin{array}{r}4.5 \\
4.5 \\
6.6 \\
5.6 \\
5.6 \\
4.8 \\
6.2 \\
6.8 \\
5.9 \\
5.7 \\
5.9 \\
8.5 \\
11.6 \\
8.8 \\
6.0 \\
6.2\end{array}$} & \multirow{10}{*}{$\begin{array}{r}1083 \\
1105 \\
1100 \\
990 \\
510 \\
464 \\
1500 \\
\\
672 \\
548 \\
688 \\
669 \\
1277 \\
1170 \\
986 \\
991\end{array}$} & \multirow{3}{*}{$\begin{array}{r}\text { mom. } \\
2.0 \\
1.5\end{array}$} & \multirow{10}{*}{$\begin{array}{l}\text { (?) Rheumatic heart disease. Very few physical signs. On } \\
\text { digitalis } \\
\text { Rheumatic heart disease. Mitral stenosis. Former pulmonary } \\
\text { hemorrhage } \\
\text { Recent rheumatic fever } \\
\text { (?) Cardiac involvement } \\
\text { Rheumatic heart disease. Advanced aortic regurgitation with } \\
\text { all peripheral signs } \\
\text { Thromboangiitis obliterans } \\
\text { Thromboangiitis obliterans } \\
\text { Heart enlarged without obvious cause } \\
\text { Nervous. Poor subject } \\
\text { Arteriosclerotic heart disease. Auricular fibrillation. On digitalis }\end{array}$} \\
\hline 118 & F. & 47 & 61 & 153 & & & & & & & & & & \\
\hline 291 & M. & 22 & 65 & 132 & & & & & & & & & & \\
\hline 292 & M. & 14 & 66 & 129 & & & & & & & & & & \\
\hline 294 & M. & 28 & 65 & 134 & & & & & & & & & 1.0 & \\
\hline 295 & M. & 30 & 68 & 144 & & & & & & & & & 1.0 & \\
\hline 296 & M. & 27 & 70 & 152 & & & & & & & & & & \\
\hline 207 & $\mathbf{M}$ & 51 & 64 & 160 & & & & & & & & & 2.0 & \\
\hline 281 & M. & 01 & 04 & 100 & & & & & & & & & 2.0 & \\
\hline 316 & M. & 48 & 68 & 171 & & & & & & & & & & \\
\hline
\end{tabular}

and it appeared from 15 to 45 minutes after the subcutaneous injection.

The action of ephedrine was rather irregular; some of our subjects responded markedly, others very little, to the same subcutaneous dose. Our results show a significant increase in pulse rate, systolic blood pressure, respiratory volume, cardiac output and cardiac work, and a significant diminution of peripheral resistance. The pattern of the response (Figure 3 ) closely resembles that found after adrenalin, but ephedrine is less power$\mathrm{ful}$ in the dosage given. The stimulant action of ephedrine on the heart is also less than that of adrenalin (Figure 1).

The increase in metabolic rate was irregular, being marked in some subjects, absent in one. This seems to have been the experience of others also (41).

The electrocardiograms of all but one of our subjects showed diminution in height of the $T$ 
wave after the drug. In Case 310 , who had been clinically much improved by the drug, an upright $\mathrm{T}$ wave became biphasic. Changes of this type have been reported on dogs and in an occasional patient after the drug (42).

The action of ephetonine, a synthetic racemic ephedrine, was carefully studied in a single normal subject by Euler and Liljestrand (43). We used the natural $l$ rotatory ephedrine which is more active than the racemic. Therefore, our results are not strictly comparable with those of Euler and Liljestrand, but they agree as well as one would expect.

The depressant action of ephedrine on the heart, demonstrated after large doses in animal experiments (42) does not seem to be a factor in the clinic after proper dosage of the drug.

As is the case with epinephrine the diminution in peripheral resistance indicates that vessels have dilated somewhere and that the increased blood pressure is to be entirely explained by increased cardiac output. Such a large increase of cardiac output accompanied by general vasoconstriction would surely cause a dangerous rise of blood pressure. Doubtless the nervous and humeral mechanisms of homeostasis, brought into action by the elevation of pressure overbalance the constrictor action of the drug.

\section{Caffeine and theophylline ethylenediamine}

These drugs, belonging to the same group, may be considered together. Both drugs, although injected well into the deltoid muscle gave rise to soreness at the site of injection in every instance. Both drugs had but little effect on the functions usually measured in the clinic-pulse rate, respiratory rate and blood pressure-so that we could do little more than guess at the time of maximum drug effect. We made the second group of estimations from 20 to 40 minutes after the injection.

The averages show a marked increase in cardiac output, work and respiration; and a diminution of peripheral resistance. These changes are significant for theophylline. Figure 3 shows that the average circulatory and respiratory effects of the two drugs have a similar pattern, theophylline being more powerful in the dosage used. Both drugs are cardiac stimulants (Figure 1).
The electrocardiograms of our patients showed no noteworthy change after either drug.

Three of the seven patients given theophylline had angina pectoris. In spite of the increased heart work demonstrated in these cases no cardiac pain followed in any instance.

Our results after intramuscular injections of caffeine correspond in a general way with those obtained by Grollman (6) after giving caffeine by mouth to normal persons. The effect of caffeine on the metabolic rate of our patients is similar to the experience of others $(6,41)$ in that, while most subjects show no change after the drug, an occasional person shows a marked increase.

In three cases of congestive heart failure, one studied three times, Friedman, Resnik, Calhoun and Harrison (44) made single estimations of cardiac output by the acetylene method before and after the oral administration of from 1.5 to 0.9 grams of theophylline daily for two days. The average of the results showed an increased cardiac output of 9.8 per cent after the drug but the results of individual experiments were irregular and this difference, judged by the standards we have set for ourselves, is not significant. These investigators were chiefly interested in the effect on the circulation of loss of fluid by diuresis, and so they had no need of performing their estimations at the height of drug action. We believe, therefore, these results to be as similar to ours as should be expected.

Our studies indicate that these two drugs rank among the powerful cardiac and circulatory stimulants. We believe that clinicians, basing judgment on their lack of effect on pulse rate, respiratory rate and blood pressure, have underestimated their activity, and possibly their value also.

\section{Carbaminoylcholine}

Carbaminoylcholine (doryl) was investigated because of the especial interest of one of the authors (45). It is a representative of the group of drugs whose action is similar to that which follows stimulation of parasympathetic nerves. Of the 6 patients, 4 were subject to peripheral vascular disease and previously had had relief of pain after the drug. All of them had improved to the extent of freedom from pain when these tests 
were made. A slight flush with some diminution of blood pressure and increase of pulse rate gave evidence that the drug was acting when the estimations were made, 20 to 40 minutes after the subcutaneous injections.

The average results, Figure 3, show a significant increase of pulse rate and respiration, and a significant diminution of blood pressure and peripheral resistance. The average cardiac output increased 12 per cent but the changes found in individual cases were irregular enough to prevent significance being attained in so small a series.

When plotted in Figure 1 the average results do not indicate any stimulant or depressant effect on the heart.

The electrocardiograms showed no change of form which could be attributed to the drug.

After doses of the size given the effects on the circulation are much similar to those which follow other vasodilators. We find no evidence of any effect like cardiac vagus stimulation.

\section{Nitrites}

All but one of the patients tested had a pronounced hypertension. A dose of 0.06 gram of sodium nitrite in solution was given by mouth as soon as the control estimations were over, and repeated about 30 minutes later just before the second inhalation of ethyl iodide began. The change in blood pressure guided us in making the two estimations of cardiac output at the height of the action of the drug. This was usually about 20 or 30 minutes after the second dose.

Case 280 was obviously excited during the control period and its data, included in Table III, have been omitted from the statistical analysis. The results show that a diminution of blood pressure occurred in all but one case, which, although given a third dose, still showed no noteworthy change. The average diminution of blood pressure and peripheral resistance are significant. The average heart work diminished with the fall in blood pressure, but there was enough variation in the individual cases to prevent significance being attained. The averages of the cardiac output and of the other functions measured were not materially influenced by the drug (Figure 3 ).

The electrocardiograms of Case 280 showed a surprising change. In Lead II the $T$ wave, up- right less than $1 \mathrm{~mm}$. before the drug, increased to $6 \mathrm{~mm}$. after it ; in Lead III the T wave, originally inverted $1 \mathrm{~mm}$., became $4 \mathrm{~mm}$. upright. The electrocardiogram during the drug's action was far more normal than that taken before it. Cases 318 and 322 showed very slight increases in height of the $\mathrm{T}$ wave in Lead II during the action, but Case 319 showed a $1 \mathrm{~mm}$. diminution of the $\mathrm{T}$ wave in this lead. The electrocardiograms of the other patients were unchanged. The changes found are similar to those described by Evans and Hoyle (46) after amyl nitrite and nitroglycerine.

Our results, Figure 1, indicate that sodium nitrite causes slight depression of the heart, a finding consistent with the results of animal experiments (22).

Sodium nitrite gives effects enduring long enough to permit duplicate estimations of cardiac output during its action. Therefore it was preferable for this investigation to the rapidly acting nitrites whose action may change materially in intensity before such estimations can be completed. However, in two cases of hypertension we obtained single estimations of cardiac output during the period of diminished blood pressure following the administration of nitroglycerine (Table III).

After a single control estimation, tablets totalling $1.2 \mathrm{mgm}$. of nitroglycerine were placed under the tongue. In the first case the pressure diminished sharply, attaining a minimum $10 \mathrm{~min}$ utes after the administration of the drug. A marked increase in cardiac output was present at that time. Forty minutes later, 20 minutes after the blood pressure had returned to its previous level, the estimated cardiac output had fallen, but not to the control level. In the second case, after a slow fall, the systolic blood pressure curve became level and did not regain its previous height during the next 35 minutes. Twenty minutes after the administration of the drug the cardiac output was but little elevated. Fifteen minutes later it was markedly increased. Obviously, there was a significant increase in cardiac output after nitroglycerine in these two cases, and the extent of the change was larger than that usually seen after sodium nitrite.

In general our results are similar to those of our predecessors in this field. Weiss and Ellis 
(47) studied 5 cases of hypertension employing the cardiac output method of Field, Bock et al. which gives higher results than the more recent methods. After doses of sodium nitrite larger than those we employed, the average cardiac output diminished 12.6 per cent. If one omits one of their cases with an abnormally high output before the drug, the diminution is only 7 per cent, in contrast to an increase of 3.4 per cent in our series. Neither change is significant and in other respects our results resemble theirs.

Gaisböck and Jarisch (48) using the Krogh and Lindhard method repeatedly on two normal subjects, found an average increase of 44 and 20 per cent in cardiac output after subcutaneous injection of small doses of sodium nitrite although the pulse rate and blood pressure were unchanged. Weiss and Ellis (47) found no change in cardiac output of normal persons after large doses by mouth. On four normal persons Lindhard (49) found a significant increase of cardiac output, averaging 23 per cent, after acute experiments with amyl nitrite. In the same subject, more prolonged inhalation was followed by a smaller effect which, judged by our standards, was not significant.

Lauber and Brauch (39) calculating the cardiac output from the pulse wave form, velocity, and pressure, according to Broemser's method, divide the action of nitroglycerine into two parts. At first output and work are increased, later both are diminished.

In general the results indicate that when the blood pressure is lowered rapidly by a nitrite the cardiac output is regularly increased. If the blood pressure falls slowly or not at all the results are less regular, either an increase or no change being found. In our series cardiac work per minute diminished, not significantly, after sodium nitrite but apparently increased in the two experiments after nitroglycerine.

\section{Pitressin}

We made four observations of pitressin action on three patients with diabetes insipidus who were accustomed to take the drug, and on three other patients who had never received it. In the former, pituitary preparations were withdrawn for about 18 hours and polyuria had developed before the control estimations. These patients' urine was measured before and after they received their usual dose at the time of testing. The polyuria was checked in every instance. Estimations were made 20 to 50 minutes after the drug's administration, usually by subcutaneous injection. Marked facial pallor gave evidence that the drug was acting when the estimations were made.

The results, Table III, do not demonstrate any obvious difference between the response of the patients with diabetes insipidus and the other patients, therefore both sets have been averaged in Table I and Figure 3. The results on Case 293, who inhaled pituitary powder, have been omitted from the statistical calculations because of lack of knowledge of the dose absorbed.

The averages show that no significant change in any item measured followed pitressin. Most of the individual results show the same thing. Case 260 showed a marked diminution of cardiac output after the drug but a second test did not confirm the finding. Case 293 alone showed a decided increase.

The electrocardiograms were unchanged after the drug except in Case 328 whose $P$ waves diminished from 2 to $1 \mathrm{~mm}$. in height in Leads II and III after the drug. We did not observe any prolongation of $\mathrm{A}-\mathrm{V}$ conduction time as has been observed both in animals and man (52).

When plotted in Figure 1, our averages do not indicate that any depression of the heart resulted from these therapeutic doses of the drug. That relatively larger doses depress the heart in heartlung and other animal preparations is well known (23).

Pituitrin is known to produce inconstant changes of blood pressure in different patients. Moffat (51) studied 62 cases; in the majority there was little or no change after $1 \mathrm{cc}$. intramuscularly. The general trend was towards a slight rise immediately after injection, and downward thereafter. Our results with pitressin are quite similar.

Grollman and Geiling (52) studied two normal subjects by the acetylene cardiac output method. Therapeutic doses of pituitrin and pitressin produced a transient diminution of pulse rate, oxygen consumption, and cardiac output, followed by a more prolonged increase. Hartl (53), calculating the cardiac output from blood pressure curves 
and pulse wave velocity according to Broemser's method, deduced an increased peripheral resistance and a diminished cardiac output after 10 units of pitressin in one subject. The curve of these results resembles that of Grollman and Geiling but the changes are not so marked and the secondary rise of cardiac output did not reach the initial level.

Our estimations of pulse rate, cardiac output and metabolism, made during the period after administration of the drug in which Grollman and Geiling obtained evidence of an increase of these functions, did not give similar results.

We have not investigated the changes in cardiac output found soon after the injection by the ethyl iodide method, but Dr. H. A. Schroeder made estimations by the acetylene method 10 minutes after the injection of 20 units of pitressin in three patients. The average output was diminished 11 per cent at this time, as found by Grollman and Geiling, but unlike their results, the metabolic rates were essentially unchanged. Varying effects of pituitrin on metabolic rate have been reported by numerous authors (52). It is of interest that in our results the changes average out.

We conclude that pitressin is a drug usually causing little enduring change in the functions we have measured. The more pronounced effects, seen occasionally, vary in their direction so that average changes are not significant.

\section{Quinidine}

The quinidine was administered by mouth and the subsequent observations were begun as soon as the action manifested itself by an increase of pulse rate, usually between one and two hours after the drug had been taken. The dosage was larger than that usually given in a single dose in the clinic. Case 285 probably received a slight overdose for she vomited after the estimations although she denied nausea during them.

Two of the cases had auricular fibrillation which persisted in spite of the drug. Two had previously been digitalized and the only instance of diminished pulse rate after quinidine occurred in one of these. In other respects the action of quinidine after digitalis did not seem different.

All the changes demonstrated after quinidine were small but some occurred with such regularity that they were significant. The average pulse rate rose significantly. The stroke volume and work per beat were significantly diminished (Table I, Figure 3).

The average size of the heart diminished significantly and this may well be a reflection of the change in heart rate. A more rapid rate, providing less time for filling, must surely reduce the diastolic size if the inflow remains unchanged.

The electrocardiograms were changed in all cases with normal rhythm, the $T$ wave being from 1 to $2 \mathrm{~mm}$. more upright in two or three leads after the drug. This was very striking in Case 282. In Case 285, Lead III, the QRS complex changed its form, the $Q$ wave originally present disappearing, and the complex becoming $M$ shaped. These results differ from those usually described, for, after patients have been given the drug daily for several days, inversion of the $T$ wave is the common finding (50). In anesthetized dogs soon after intravenous injection of quinidine Lewis et al. (54) described an elevation of the $T$ wave probably analogous to that seen in our acute experiments.

By means of animal experiments quinidine has been proved a strong cardiac depressant. The average results do not demonstrate cardiac depression in our subjects, although they received larger doses than usual. Perhaps clinical experience has set the dosage of quinidine at a point where cardiac depression is minimal.

\section{Morphine}

This drug was the first studied, and our data are less complete than in other groups. The size of the heart after the administration of the drug was estimated in only four cases, the electrocardiogram was taken in but one.

Seven determinations were performed on patients without heart disease and not seriously ill. The estimations during morphine action were made as soon as pupillary constriction was manifest, and were performed between $1 / 2$ and $1 \frac{1}{2}$ hours after the subcutaneous injection. The averages (Table I and Figure 3) show little change in heart or circulation. The largest change was in the average pulse rate which diminished about 5 per cent, but even this did not attain signifi- 
cance. Changes in respiration were more pronounced, that of the rate being significant.

Eight cases of severe cardiac disease, all severely ill but none of them in congestive failure, were given slightly larger doses. The sedative and pupillary effects were very obvious in each case. Two of the three patients, receiving 0.03 gram, vomited some hours after the test was over but, like the other patients, they denied any nausea or discomfort during it. Again the changes in heart and circulation were slight (Figure 3 ). The average pulse rate is less affected than in the non-cardiac group, but the metabolism, cardiac output and work were diminished somewhat more. The depression of respiration was again marked, the change in volume was significant.

The effect on heart size was determined on only four patients. When these results are plotted, Figure 1, cardiac depression is suggested, but the change is not significant. Such an effect is in accord with the action of morphine on the isolated heart but the paucity of our data prevents us from placing emphasis on the finding.

The results we obtained on pulse and respiratory rate and on basal metabolic rate were all similar to those of previous investigators $(41,55)$ who found no change or very small reductions in these functions after morphine. Depression of respiration by morphine, shown in our results, is in accord with expectations from animal experiments and from studies on patients with pneumonia (56).

That morphine benefits patients severely ill with cardiac disease is unquestioned. The usual explanation is that the drug, by quieting the patient, reduces the metabolic rate and so permits a slower circulation maintained by reduced cardiac effort. We regard our results as giving slight support to this conception. The diminution of cardiac work after morphine is somewhat more obvious in our cardiac cases, though absent in the more normal persons. In still more restless patients a greater reduction in both metabolic rate and cardiac work would be expected.

\section{Strychnine}

As strychnine was used in the therapy of cardiac disease some years ago we utilized cardiac patients whenever they could be secured. We had no way of assuring ourselves that the drug was acting when the estimations were made. Knowing well that the effects could be expected to pass off rapidly we made the post-drug estimations from 10 to 30 minutes after subcutaneous injection. Case 297 appeared to be excited during the control estimations and these results have been omitted from the statistics although they are consistent with the other findings.

The average results, Figure 3, indicate that only mild effects can be attributed to the drug. No noteworthy stimulation of respiration appeared, except perhaps in Case 296, but we believe that a finding occurring only once is more likely to be an artifact. There was an increase in peripheral resistance and a small diminution of most of the other items measured. The findings in individual cases are quite consistent so that significance is approached in several instances and attained in the case of work per beat.

When plotted on Figure 1, the results do not indicate any stimulant effect on the heart.

The electrocardiograms showed no noteworthy change which could be attributed to the drug.

Attracted by the fact that Margolies found slight diminution in the size of the heart after strychnine in the first six cases not taking digitalis, this part of our study was continued in the outpatient department. Six patients not on digitalis were selected. All had well marked heart disease and four had markedly enlarged hearts. Orthodiagrams, made about 45 minutes after 2 mgm. of strychnine subcutaneously, showed no diminution of heart size in any case.

Our results give no support to the old belief, now generally abandoned, that strychnine stimulates the heart. On the other hand they cannot be dismissed as negative. Slight vasoconstriction with enough diminution of cardiac output to keep the blood pressure constant is suggested. Vasoconstriction in the splanchnic vessels, attributed to stimulation of the vasomotor center, is a well known action of this drug in animal preparations (23). Wenckebach has advocated the clinical use of strychnine in hypotonic cases (57). Our results are of interest in this connection.

\section{GENERAL DISCUSSION}

As a general rule our results demonstrate that the effects of drugs on patients are analogous to 
comparable results obtained in animal experiments. One exception must be pointed out.

The drugs which give cardiac stimulation in animal experiments cause a similar effect on the patients receiving them in therapeutic dosage. But, in proper clinical doses, the cardiac depressants cause no depression in patients at all comparable with that which may be demonstrated in animal experiments.

In other words, as generally used in the clinic, the stimulants cause marked cardiac stimulation, the depressants are followed by little, if any, demonstrable depression of myocardial function. Doubtless clinical experience has set the proper dose of the depressants at a level at which the heart is but little handicapped by this phase of their action.

\section{SUMMARY}

The subjects consisted of 85 patients suffering chiefly from cardiac or circulatory disease but not from congestive heart failure. The number of patients tested for the effects of each drug varied from 2 to 16.

The drugs investigated included digitalis, epinephrine, ephedrine, caffeine, theophylline, carbaminoylcholine, sodium nitrite, nitroglycerine, pitressin, quinidine, morphine and strychnine. As far as possible we studied the action of drugs given under the conditions in which physicians are accustomed to employ them.

The study consisted of a group of estimations made before, during, and sometimes after the drugs' action. This group consisted of duplicate determinations of cardiac output and metabolic rate; and repeated estimations of pulse rate, blood pressure, respiratory rate and volume. Orthodiagrams and electrocardiograms were secured also.

Based on a conception derived by Starling and his associates from the behavior of the dog's heart-lung preparation, a method has been devised for estimating the extent of myocardial stimulation or depression occurring during drug action in the clinic.

A statistical analysis of the data affords a basis for describing the action to be expected after the administration of these drugs in clinical conditions. With but few exceptions our results sup- port the general conceptions of drug action derived from animal experiments.

The tables contain data on the basal cardiac output and its related functions in many common diseases of the heart and circulation.

\section{BIBLIOGRAPHY}

1. Starr, I., Jr., and Gamble, C. J., An improved method for the determination of cardiac output in man by means of ethyl iodide. Am. J. Physiol., 1928, 87, 450.

2. Donal, J. S., Jr., Gamble, C. J., and Shaw, R., The cardiac output in man. An adaptation of the katharometer for the rapid determination of ethyl iodide in estimations of cardiac output by the ethyl iodide method. A study of the effect of posture upon cardiac output and other circulatory and respiratory measurements. Am. J. Physiol., 1934, 109, 666.

3. Starr, I., Jr., Collins, L. H., Jr., and Wood, F. C., Studies of the basal work and output of the heart in clinical conditions. J. Clin. Invest., 1933, 12, 13.

4. Bazett, H. C., Cotton, F. S., Laplace, L. B., and Scott, J. C., The calculation of cardiac output and effective peripheral resistance from blood pressure measurements with an appendix on the size of the aorta in man. Am. J. Physiol., 1935, 113, 312.

5. Kahlstorf, A., Uber Korrelationen der Linearen HerzMasse und des Herzvolumens. Klin. Wchnschr., 1933, 12, 262.

6. Grollman, A., The Cardiac Output of Man in Health and Disease. C. C. Thomas, Baltimore, 1932.

7. Fisher, R. A., Statistical Methods for Research Workers. Oliver and Boyd, London, 1930, 3d ed., pp. 104, 105. 106, and 139.

8. Nylin, G., Clinical tests of the function of the heart. Acta med. Scandinav., 1933, Supp. 52.

9. Pearson, K., Tables for Statisticians and Biometricians, Part I. Cambridge University Press, England, 1930, Table XIX.

10. Starr, I., Jr., and Gamble, C. J., Cardiac output in common clinical conditions, and the diagnosis of myocardial insufficiency by cardiac output methods. Ann. Int. Med., 1935, 9, 569.

11. Starling, E. H., The Linacre Lecture on the Law of the Heart. Longmans, Green and Co., London and New York, 1918.

12. Starr, I., Jr., Donal, J. S., Margolies, A., Shaw, R., Collins, L. H., and Gamble, C. J., Studies of the heart and circulation in disease; estimations of basal cardiac output, metabolism, heart size, and blood pressure in 235 subjects. J. Clin. Invest., 1934, 13, 561.

13. Bodo, R., The effect of the "heart tonics" and other drugs upon the heart-tone and coronary circulation. J. Physiol., 1928, 64, 365. 
14. Starr, I., Jr., Donal, J. S., Margolies, A., and Gamble, C. J., The action of drugs on myocardial function in cardiac and circulatory disease. J. Clin Invest. (Proc.), 1935, 14, 700.

15. Bay, E. B., The work of the left ventricle in aortic insufficiency. J. Clin. Invest., 1936, 15, 643.

16. Lewis, T., Studies of capillary pulsation, with special reference to vasodilatation in aortic regurgitation and including observations on the effects of heating the human skin. Heart, 1924, 11, 151.

17. Hallock, P., Arterial elasticity in man in relation to age as evaluated by the pulse wave velocity method. Arch. Int. Med., 1934, 54, 770.

18. Whittaker, S. R. F., and Winton, F. R., The apparent viscosity of blood flowing in the isolated hindlimb of the dog, and its variation with corpuscular concentration. J. Physiol., 1933, 78, 339.

19. Burwell, C. S., Neighbors, DeW., and Regen, E. M., The effect of digitalis upon the output of the heart in normal man. J. Clin. Invest., 1928, 5, 125.

20. Stewart, H. J., and Cohn, A. E., Studies on the effect of the action of digitalis on the output of blood from the heart. III. Part 1 . The effect on the output in normal human hearts. Part 2. The effect on the output of hearts in heart failure with congestion, in human beings. J. Clin. Invest., 1932, $11,917$.

21. Harrison, T. R., Failure of the Circulation. Williams and Wilkins Co., Baltimore, 1935.

22. Cushny, A. R., The Action and Uses in Medicine of Digitalis and Its Allies. Longmans, Green \& Co., London, 1925.

23. Edmunds and Gunn. In Cushny, A. R., A Textbook of Pharmacology and Therapeutics. Lea and Febiger, Philadelphia, 1936, 11th ed.

24. Luten, D., The Clinical Use of Digitalis. C. C. Thomas, Springfield, Ill., 1936.

25. Weese, H., Digitalis. G. Thieme, Leipzig, 1936.

26. Harrison, T. R., and Leonard, B. W., The effect of digitalis on the cardiac output of dogs and its bearing on the action of the drug in heart disease. J. Clin. Invest., 1926, 3, 1.

27. Ringer, M., and Altschule, M., Studies on the circulation. II. Cardiac output in diseases of the heart and under the influence of digitalis therapy. Am. Heart J., 1930, 5, 305.

28. Lauter, S., and Baumann, H., Zur Theorie der Herzinsuffizienz und der Digitaliswirkung. Klin. Wchnschr., 1929, 8, 263.

29. Kininmonth, J. G., The circulation rate in some pathological states with observations on the effect of digitalis. Quart. J. Med., 1928, 21, 277.

30. Eppinger, H., von Papp, L., and Schwarz, H., Ueber Das Asthma Cardiale. Springer, Berlin, 1924.

31. Schwarz, H., and Schimmer, F., Zur Bestimmung des Herzminutenvolums beim Menschen. Ztschr. f. d. ges. exper. Med., 1929, 64, 303.
32. Ewig, W., and Hinsberg, K., Kreislaufstudien. II. Ztschr. f. klin. Med., 1931, 115, 693.

33. Grassmann, W., and Herzog, F., Die Wirkung von Digitalis (Strophanthin) auf das Minuten- und Schlagvolumen des Herzkranken. Arch. f. exper. Path. u. Pharmakol., 1931, 163, 97.

34. Broemser, P., and Ranke, O. F., Ueber die Messung des Schlagvolumens des Herzens auf unblutigem Weg. Ztschr. f. Biol., 1930, 90, 467.

35. Friedman, B., Clark, G., Resnik, H., Jr., and Harrison, T. R., Effect of digitalis on the cardiac output of persons with congestive heart failure. Arch. Int. Med., 1935, 56, 710.

36. Blumgart, H. L., The Circulatory Response to Epinephrine. Libman Anniversary Volumes, 1932, $1,215$.

37. Euler, U. v., and Liljestrand, G., Die Wirkung des Adrenalins auf das Minutenvolumen des Herzen beim Menschen. Skandinav. Arch. f. Physiol., 1927, 52, 243.

38. Field, H., Jr., and Bock, A. V., The action of adrenalin chloride on the circulation in man. J. Clin. Invest. (Proc.), 1924-5, 1, 581.

39. Lauber, H., and Brauch, F., Uber pharmakologische Beeinflussung der Zirkulationsgrösse und Herzarbeit des Menschen. Ztschr. f. klin. Med., 1930, $114,120$.

40. Clough, P. W., A study of the cardiovascular reaction to epinephrin. Epinephrin sensitiveness in patients with hypertension. Bull. Johns Hopkins Hosp., 1920, 31, 266.

41. Boothby, W. M., and Rowntree, L. G., Drugs and basal metabolism. J. Pharmacol. and Exper. Therap., 1923, 22, 99.

42. Chen, K. K., and Schmidt, C. F., Ephedrine and Related Substances. Williams \& Wilkins Co., Baltimore, 1930.

43. Euler, U. v., and Liljestrand, G., Die Wirkung von Adrenalin, Sympathol, Tyramin, Ephetonin und Histamin auf Gaswechsel und Kreislauf beim Menschen. Skandinav. Arch. f. Physiol., 1929, $55,1$.

44. Friedman, B., Resnik, H., Jr., Calhoun, J. A., and Harrison, T. R., Effect of diuretics on the cardiac output of patients with congestive heart failure. Arch. Int. Med., 1935, 56, 341.

45. Starr, I., Carbaminoylcholine (Doryl or Lentin), its action on normal persons, in peripheral vascular disease and in certain other clinical conditions. Am. J. M. Sc., 1937, 193, 393.

46. Evans, W., and Hoyle, C., The effects of nitrite on the inverted $T$ wave in the human electrocardiogram. Lancet, 1933, 1, 1109.

47. Weiss, S., and Ellis, L. B., Influence of sodium nitrite on the cardiovascular system and on renal activity in health, in arterial hypertension and in renal disease. Arch. Int. Med., 1933, 52, 105. 
48. Gaisböck, F., and Jarisch, A., Ueber den Einfluss von Natrium nitrosum auf den Kreislauf. Wien. klin. Wchnschr., 1927, 40, 1540.

49. Lindhard, J., Uber das Minutenvolumen des Herzens bei Ruhe und bei Muskelarbeit. Arch. f. d. ges. Physiol., 1915, 161, 233.

50. Pardee, H. E. B., Clinical Aspects of the Electrocardiogram. Paul B. Hoeber, New York, 1933, 3d ed.

51. Moffat, W. M., The effect of pituitrin injections on blood pressure in man. Am. J. M. Sc., 1933, 186, 854.

52. Grollman, A., and Geiling, E. M. K., The cardiovascular and metabolic reactions of man to the intramuscular injection of posterior pituitary liquid (pituitrin), pitressin and pitocin. J. Pharmacol. and Exper. Therap., 1932, 46, 447.
53. Hartl, K., Die Wirkung des Pitressin auf Kreislauf und Atmung. Arch. f. exper. Path. u. Pharmakol., 1933, 173, 133.

54. Lewis, T., Drury, A. N., Iliescu, C. C., and Wedd, A. M., Observations relating to the action of quinidine upon the dog's heart with special reference to its action on clinical fibrillation of the auricles. Heart, 1921-2, 9, 55.

55. Higgins, H. L., and Means, J. H., The effect of certain drugs on the respiration and gaseous metabolism of normal human subjects. J. Pharmacol. and Exper. Therap., 1915, 7, 1.

56. Davis, J. S., Jr., The effect of morphine on the respiration in pneumonia. J. Clin. Invest., 1928-9, 6, 187.

57. Wenckebach, K. F., The use of foxglove at the bedside. Brit. M. J., 1930, 1, 181. 